\title{
Morphodynamic development and sediment budget of the Dutch Wadden Sea over the last century
}

\author{
E.P.L. Elias ${ }^{1,}{ }^{*}$, A.J.F. van der Spek ${ }^{1,2,3}$, Z.B. Wang ${ }^{1,2}$ \& J. de Ronde ${ }^{1}$ \\ 1 Deltares, P.0. Box 177, 2600 MH Delft, the Netherlands. \\ 2 Faculty of Civil Engineering and Geosciences, Delft University of Technology, P0 Box 5048, 2600GA Delft, the Netherlands. \\ 3 UNESCO-IHE, Institute for Water Education, P0 Box 3051, 2601 DA Delft, the Netherlands. \\ * Corresponding author. Email: edwin.elias@deltares.nl.
}

Manuscript received: May 2011, accepted: May 2012

\begin{abstract}
The availability of nearly 100 years of bathymetric measurements allows the analysis of the morphodynamic evolution of the Dutch Wadden Sea under rising sea level and increasing human constraint. The historically observed roll-over mechanisms of landward barrier and coastline retreat cannot be sustained naturally due to numerous erosion control measures that have fixed the tidal basin and barrier dimensions. Nevertheless, the large continuous sedimentation in the tidal basins (nearly 600 million $\mathrm{m}^{3}$ ), the retained inlets and the similar channel-shoal characteristics of the basins during the observation period indicate that the Wadden Sea is resilient to anthropogenic influence, and can import sediment volumes even larger than those needed to compensate the present rate of sea-level rise. The largest sedimentation occurs in the Western Wadden Sea, where the influence of human intervention is dominant. The large infilling rates in closed-off channels, and along the basin shoreline, rather than a gradual increase in channel flat heights, render it likely that this sedimentation is primarily a response to the closure of the Zuiderzee and not an adaptation to sea-level rise. Most of the sediments were supplied by the ebb-tidal deltas. It is, however, unlikely that the sediment volume needed to reach a new equilibrium morphology in the Western Wadden Sea can be delivered by the remaining ebb-tidal deltas alone.
\end{abstract}

Keywords: Wadden Sea, morphodynamics, tidal basins, ebb-tidal deltas, impact large-scale engineering works

\section{Introduction}

The Wadden Sea is the world's largest uninterrupted system of tidal flats and barrier islands. Over a period of more than 7000 years a wide variety of barrier islands, channels, sand and mud flats, gullies and salt marshes formed under a temperate climate, rising sea level, and, especially during the last century, human interventions. The geological evolution of the Dutch coast showed that the Holocene Wadden Sea could keep up with relative sealevel rise. Relative sea-level rise caused expansion of the basin, which increased the volume of sediment accommodation space and generated a net landward sediment transport. Erosion of the adjacent shorelines contributed significantly to the sediment supply, leading to landward retreat of the entire barrier-inletbasin system with conservation of its basic characteristics (see e.g. Van Straaten, 1975; Flemming \& Davis, 1994).
In recent times, increasing population density, extensive coastal development and shoreline protection structures such as dykes, seawalls, revetments, groins and jetties have increasingly impacted or constrained the natural dynamics of many coastal systems including the Wadden Sea. sea-level rise is likely to accelerate in the future due to global warming, (e.g., Meehl et al., 2007). Field observations suggest that some systems remain stable as sediment import, tidal-flat and salt marsh accretion can keep pace with certain rates of relative sea-level rise (Nichols, 1989; Van der Spek \& Beets, 1992; Cahoon et al., 2000; Morris et al., 2002; Bartholdy et al. 2007; Madsen et al., 2007), while other systems degrade and finally drown (Kennish, 2001; Van Wijnen \& Bakker, 2001). It is however uncertain whether, or how, anthropogenic pressure might impede the ability of natural systems, such as the Wadden Sea, to respond to changing conditions in the future, especially in the 
scope of climate change. Therefore, it is of prime importance to understand both the short-term and long-term dynamics of coastal estuaries and tidal basins under the influence of anthropogenic disturbances and climate change.

The study of the consequences of engineering works on the long-term functioning of inlet systems is a relatively unexplored field of research. In this respect the absence of datasets comprising frequent observations over relevant long time frames plays an important role. In addition, only a few proven predictive methods are available to assess the impact of accelerated sea-level rise on inlet systems. Predictions of shoreline change as proposed by Bruun (1962) and Stive \& Wang (2003) might work along uninterrupted beach/dune coasts, although the assumptions underlying the concept are not supported by oceanographic and geologic evidence (Pilkey et al., 1993). However, these types of predictions are generally too simplistic to account for complex inlet processes, where ebb-tidal delta, inlet channel and back-barrier basin tend to remain in dynamic equilibrium to the large-scale hydraulic forcing, individually as well as collectively (Dean, 1988; 0ost \& de Boer, 1994; Stive et al., 1998; Stive \& Wang, 2003). Van Goor et al. (2003) explicitly assume such dynamic equilibrium in order to predict critical rates of sea-level rise for various tidal inlet/basin systems in the Dutch Wadden Sea. Their model needs parameters which ideally should be derived from process-based modeling or measurements (Wang et al., 2007). Coastal process-based models that contain the necessary physics to account for these complex interactions, like Delft3D (Lesser et al., 2004), and ROMS (Shchepetkin \& McWilliams, 2005), are only just starting to address morphodynamic changes on relevant long time scales (see examples in Hibma et al., 2003; Marciano et al., 2005; Dastgheib et al., 2008; Van der Wegen \& Roelvink, 2008; Van der Wegen et al., 2008).

Frequent bathymetric measurements of the Dutch part of the Wadden Sea since the early nineteenth century have resulted in a unique dataset that allows the analysis of its morphodynamic evolution under rising sea level and human constraint. Since 1925/1935 the bathymetric surveys are sufficiently detailed to allow a sediment budget study. Through analysis of the observed morphological changes, we aim to contribute to the general understanding of medium- to long-term tidal inlet/basin morphodynamics. This information can be used to better estimate the potential response to sealevel rise of the Dutch Wadden Sea and similar tidal basin and wetland systems in the German and Danish Wadden Sea and along the east coast of the United States.

\section{Study area}

\section{General setting}

The Wadden Sea is the world's largest coastal wetland formed by an uninterrupted stretch of tidal flats and barrier islands that span a distance of nearly $500 \mathrm{~km}$ along the northern part

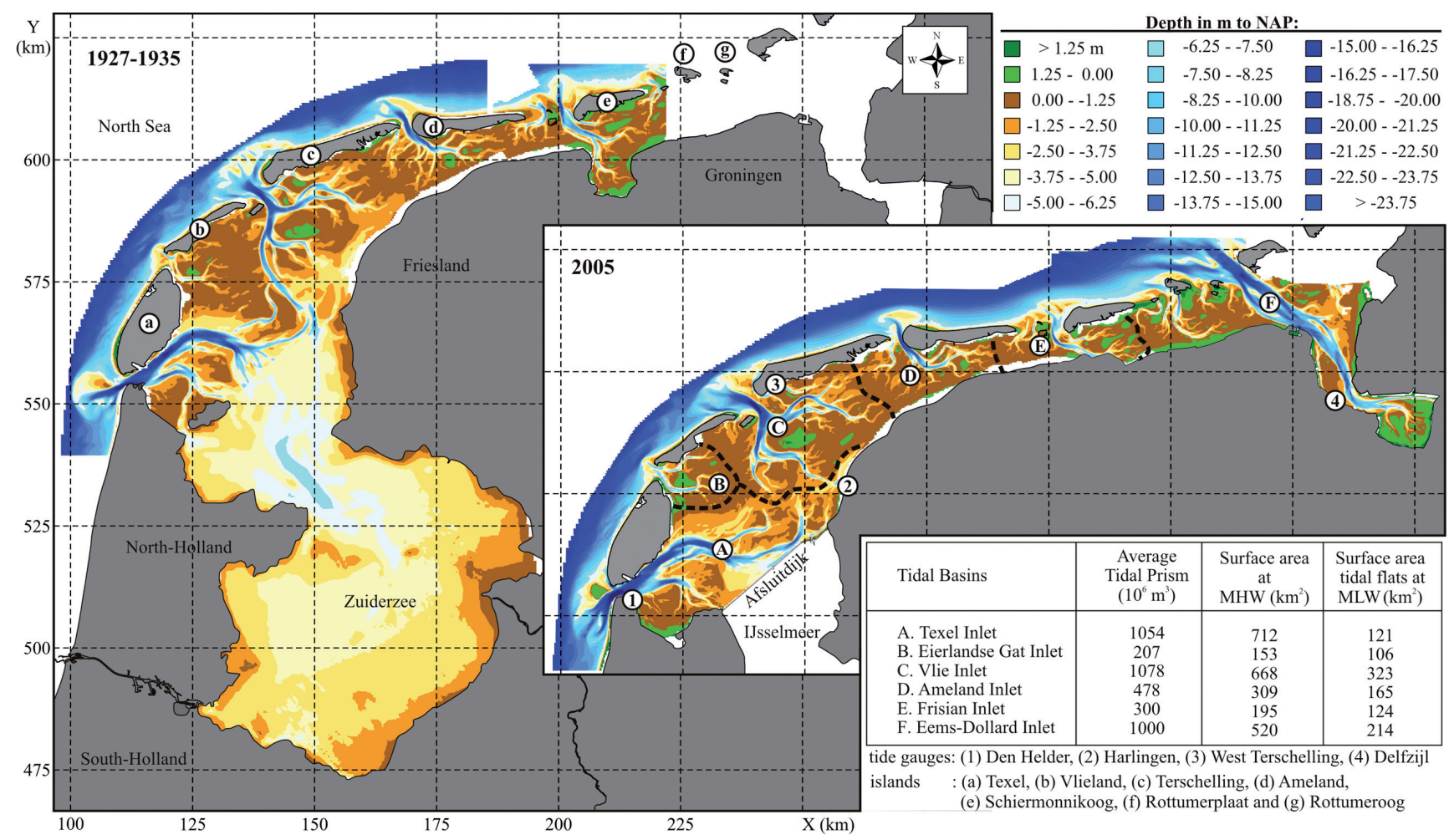

Fig. 1. Representative maps of the Dutch Wadden Sea illustrating the configuration of the inlets, basins, channels and shoals for the years $1927-1935$ (large figure) and 2005 (lower right). The main characteristics of the individual inlet systems are indicative for the present situation and based on Louters \& Gerritsen (1994). 
of the Netherlands and German coast and the North Sea coast of Denmark. The associated barrier islands separate the approximate $10,000 \mathrm{~km}^{2}$ of tidal flats from the North Sea and contain extensive systems of branching channels, sand and mud flats, and salt marshes. The tidal flats are mainly composed of sand ( $90 \%)$ and fine-grained muddy sediments ( 10\%), with decreasing grain size away from the inlet (Van Straaten, 1954; De Glopper, 1967; Nyandwi, 1998; Bartholomä \& Flemming, 2007) due to the settling lag effects of suspended sediments (Postma, 1954, 1961; Van Straaten \& Kuenen, 1957).

Figure 1 shows the main tidal inlets for the Dutch part of the Wadden Sea. The Dutch inlets consist of relatively large ebb-tidal delta shoals, narrow and deep inlet channels, and extensive systems of branching channels, tidal flats and salt marshes in the back-barrier basins. Two distinct differences in geometry can be observed between the inlets in the western and eastern part of the Dutch Wadden Sea. Firstly, in eastward direction, the coastline orientation changes from south-north to west-east due to the underlying Pleistocene morphology. Secondly, the back-barrier area of the eastern part (Ameland inlet, Frisian inlet, Eems-Dollard flats) is relatively narrow and shallow, with comparatively large tidal-flat areas and small channels; the ratio of intertidal area versus total surface area varies between 0.6 and 0.8 (Stive \& Eysink, 1989). In the western part, the basin is wider and the ratios of intertidal area versus total surface area are 0.3 to 0.4 . These latter low values are caused by the large dimensions of the tidal channels that fed the former Zuiderzee and the geologically young age of this part of the Wadden Sea. The construction of the closure dam 'Afsluitdijk' in 1932 separated the shallow Zuiderzee from the active basins, rendering these tidal channels too large for their new function (Elias et al., 2003; Elias \& Van der Spek, 2006).

\section{Mixed-energy environments}

Both tides and waves play an important role in shaping and maintaining the Wadden system. In general, following the classification of Davis \& Hayes (1984), the inlets qualify as mixedenergy wave-dominated, even under spring-tide conditions. However, the morphology of the major inlets shows tidedominated characteristics such as a large ebb-tidal delta and deep entrance channels. These result from large tidal prisms and relatively low wave energy (Davis \& Hayes, 1984). On the ebb-tidal deltas, waves redistribute the sediments and contribute to the sediment bypassing mechanism (FitzGerald, 1988; Sha, 1989). The wave climate consists mainly of local windgenerated waves in the shallow North Sea basin. The mean significant wave height is $1.3 \mathrm{~m}$ from the west-southwest, with a corresponding mean wave period of 5 seconds (Roskam, 1988; Wijnberg, 1995). During storms, wind-generated waves occasionally reach heights of over $6 \mathrm{~m}$ and additional waterlevel surges of more than $2 \mathrm{~m}$ have been measured.
North Sea tides are driven by the tidal (Kelvin) waves entering from the Atlantic 0cean between Scotland and Norway in the north, and through the Dover Strait in the south. Interference of these two waves, distortion due to Coriolis effects and bottom friction generates a complicated tidal flow pattern in the southern part of the North Sea (Pugh, 2004). The tides spin in a whirl with anti-clockwise rotation around 2 central (amphidromic) points. At the amphidromic point the tidal amplitude is zero and the tidal range increases with distance to the amphidromic point. Along the Dutch coast a combination of a standing and progressive tidal wave propagates from south to north, thereby generating maximum shore parallel tidal velocities in the range of 0.5 to $1.0 \mathrm{~m} / \mathrm{s}$. Near Texel inlet this northward-travelling tidal wave meets a second eastward travelling tidal wave, and the combined waves propagate from the west to east along the Wadden Sea Islands and into the basins. The mean tidal range thereby increases from $1.4 \mathrm{~m}$ at Den Helder to $2.5 \mathrm{~m}$ in the Ems estuary (EemsDollard Inlet) and increases even further along the German Wadden coast.

The tidal processes of flooding and draining are the driving force for the fractal channel patterns in the basin (Cleveringa \& Oost, 1999; Marciano et al., 2005). Facing the inlet mouths are bulky ebb-tidal deltas that are maintained by the large sediment transport capacity of the tidal currents in the inlets. Tidal divides between the basins are formed where the tidal waves travelling through two adjacent inlets meet and sedimentation due to near-zero velocities results in tidal-flat formation (Fig. 1). These tidal divides are often considered to form the boundaries of the separate inlet systems and are located somewhat eastward of the center of the barrier islands due to the amplitude differences between the neighboring inlets (Wang et al., 2011) and the prevailing eastward wind direction (FitzGerald, 1996).

Supply of fresh water and sediment by rivers to the Dutch Wadden Sea is limited, and dominated by discharges from Lake 'IJsselmeer' through drainage sluices in the closure dam Afsluitdijk. Even though discharge volumes are minor relative to the inlets tidal fluxes (year averaged $450 \mathrm{~m}^{3} / \mathrm{s}$ ), density gradients due to salinity and temperature might play an important role in the sediment exchanges through the inlets (Elias et al., 2005; Burchard et al., 2008).

\section{Sea-level rise}

Measurements of the mean sea level over the last 150 years reveal a fairly constant increase of $0.20 \mathrm{~m}$ per century along the Dutch coast (Deltacomissie, 1960; Baart et al., 2012). Local measurements indicate a 0.12 to $0.14 \mathrm{~m}$ per century increase along the Wadden Sea (Fig. 2). It is anticipated that worldwide sea-level rise will accelerate between $0.18 \mathrm{~m}$ and $0.59 \mathrm{~m}$ by 2100 due to global warming (Meehl et al., 2007). Along the Dutch coast these increases are estimated to range between 


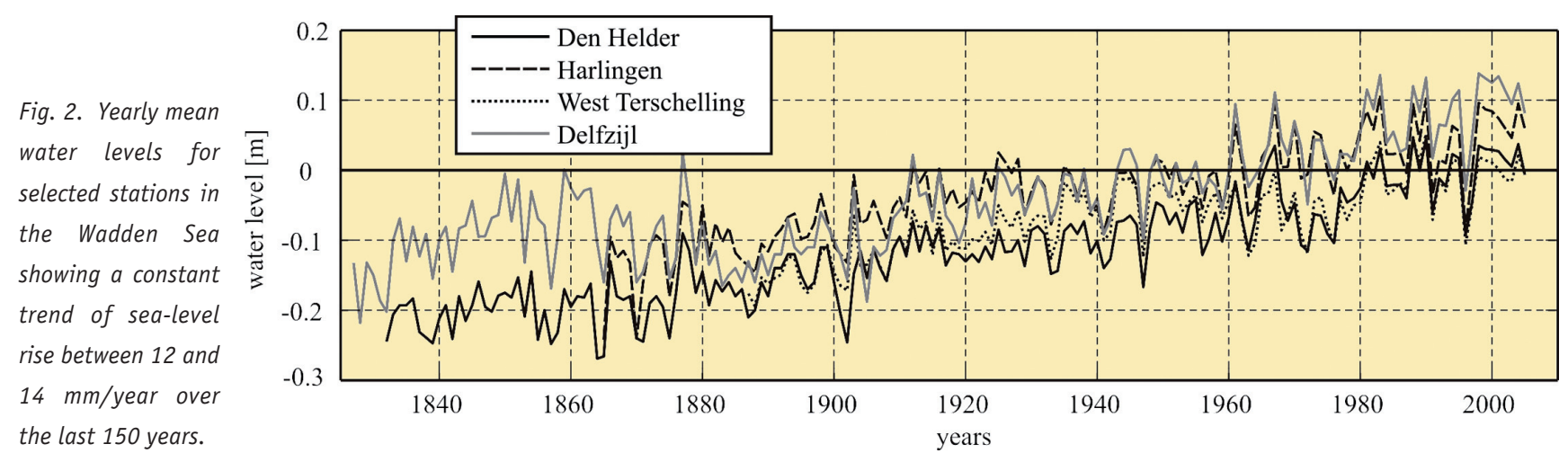

0.35-0.85 $\mathrm{m}$ by the end of the $21^{\text {st }}$ century, and 2 to $4 \mathrm{~m}$ by 2200 (Katsman et al., 2009). In addition, sea-floor subsidence due to glacial isostacy and compaction adds $0.10 \mathrm{~m}$ till 2100 . Locally, in the eastern part of the Dutch Wadden Sea, an extra subsidence of $0.32 \mathrm{~m}$ by 2050 due to gas extraction is expected (Hoeksema et al., 2004).

Valuable lessons on the effects of sea-level rise on the natural system can be learned from the past, as the formation and subsequent evolution of tidal basins under the influence of rising sea levels largely determined the Holocene evolution of the Dutch coast (Zagwijn, 1986; Van der Spek, 1994; Beets \& Van der Spek, 2000; De Mulder et al., 2003;). Several cycles of marine ingression and subsequent basin sedimentation, and sufficient sediment supply to retain or even prograde the coastline due to the presence of major sediment sources, finally filled in the entire western part of the Dutch coastal plain. Van der Spek (1994) summarises: rising sea levels and/or landsurface subsidence create storage potential in the coastal plain, leading to ingression by the sea. Available accommodation space induces net landward sediment transport and basin infilling. The supply of sediment determines the coastal evolution. An abundant supply will lead to infilling of the basins and even progradation of the coast (Nichols, 1989). A deficient sediment supply will prevent infilling of the basins and will lead to landward shift of the coastal system with relative sea-level rise. Part of the sediments is delivered by the barriers and coasts adjacent to the tidal inlet, which leads to retreat of the coastline. Sediment supply along the Wadden Sea was sufficient to retain the extensive systems of tidal flats and salt marshes over the past 7000 years, but insufficient to fill in the basin completely (see e.g., Van der Molen \& Van Dijck, 2000). The major anthropogenic influences since human settlement might just have changed the natural dynamics.

\section{Recent history of the Western Wadden Sea}

The rise in sea level led to gradual flooding of the Pleistocene high in the present-day Western Wadden Sea, leading to expansion of this part of the tidal basin and finally a connection to an inland lake area (Lake Flevo, the precursor of Zuiderzee). Thus Vlie inlet was formed around 2000 years ago.
Subsidence of the surface level, both natural and man-induced due to excavation and drainage of low-lying peat areas bordering the inlet's initial basin for agricultural use, added to this (Schoorl, 1973; Westenberg, 1974; Pons \& Van 0osten, 1974; Eisma \& Wolff, 1980). By $800 \mathrm{AD}$ the peat landscape had changed into an intertidal area (Vos et al., 2011). Texel inlet is believed to have evolved from a small, local drainage channel that also connected to the inland Zuiderzee around the $12^{\text {th }}$ century AD after a series of severe storm events (Schoorl, 1973; Hallewas,

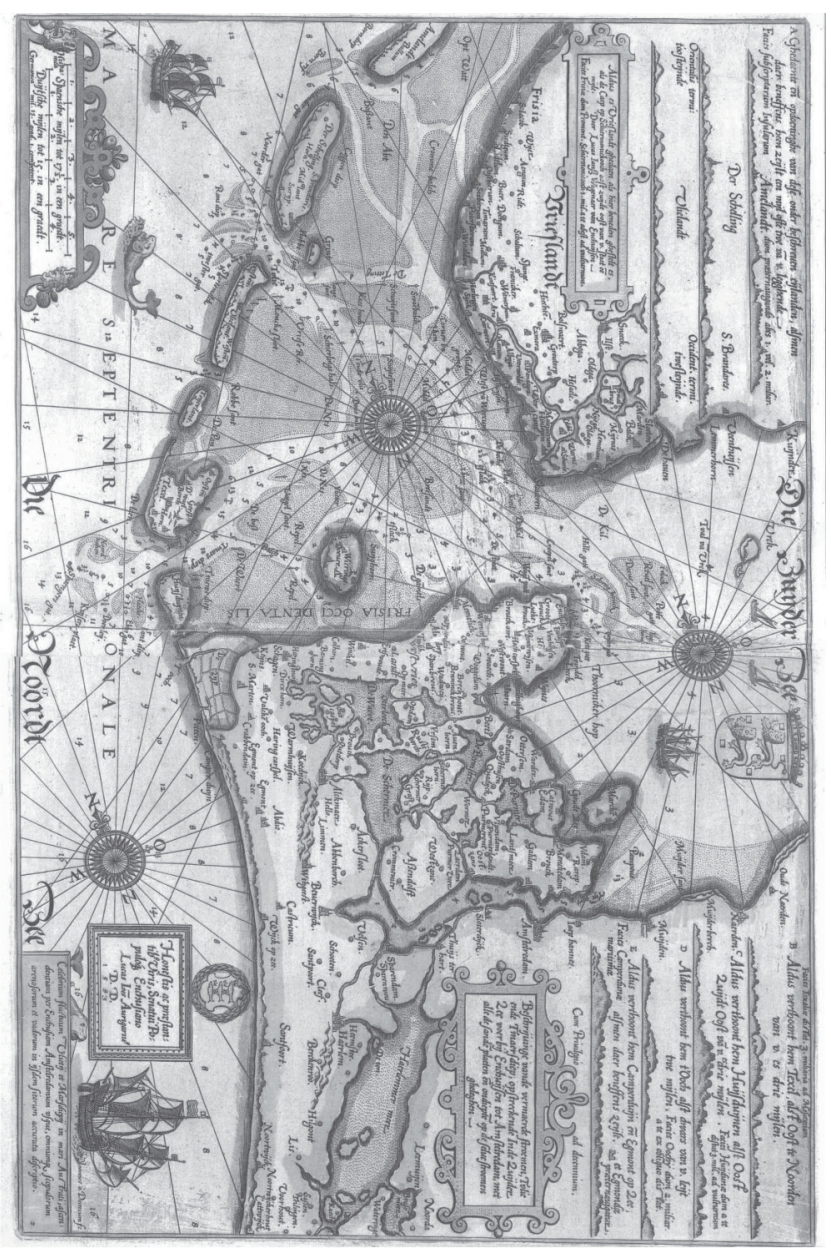

Fig. 3. Transition to an 'engineered system'; map of the Western Wadden Sea drawn in 1584 by Lucas Jansz Waghenaer in 'Spieghel der Zeevaerdt'. Not to scale. 
1984). Connection to the inland Zuiderzee increased the tidal prisms of the Vlie and Marsdiep inlets, which subsequently became the largest inlets in the Dutch Wadden Sea.

Human interventions gradually started to influence the Wadden Sea evolution from the Middle Ages onward. Dyke construction began around the $10^{\text {th }}$ century, and several formerly flooded areas such as the Middelzee between the $10^{\text {th }}$ and $13^{\text {th }}$ century (Van der Spek, 1995), the Lauwerszee since the $13^{\text {th }}$ century (Oost, 1995) and parts of the Ems-Dollard estuary were (partly) filled in or reclaimed. Smaller scale dykes were constructed since $1000 \mathrm{AD}$ to locally protect villages and reclaimed lands. These early dykes were low and near decadal large-scale flooding occurred (e.g., 1675, 1686, 1697, 1717, $1825 \mathrm{AD}$ ). Dyke building intensified in the $16^{\text {th }}$ century by adding wooden pilings and groins and increasing dimensions. Figure 3 illustrates the western part of the Wadden Sea at that time. Catastrophic flooding by a storm surge in 1916 triggered the largest intervention ever in the Wadden Sea, complete closure of the Zuiderzee (see Fig. 1 for location). The closure dam Afsluitdijk was completed in 1932. Major flooding in 1953 lead to the additional, smaller scale, closure of the Lauwerszee, that was completed in 1969 (Fig. 1). The reduced basin dimensions after the closures of the Zuiderzee and Lauwerszee, in combination with dykes protecting the remainder of the mainland, formed the Wadden Sea as we know it today (Biegel \& Hoekstra, 1995; 0ost, 1995; Elias \& Van der Spek, 2006).

In addition to basin constrictions, the natural evolution and movement of the seaward barrier islands was increasingly limited by reinforcing existing dunes, island tip protections (e.g., seawalls, jetties and groins) and sand nourishments. Already in the early $17^{\text {th }}$ century, defensive works in the form of wooden groins and under-water willow mattresses were placed at the tip of North Holland to retard the erosion caused by migration and expansion of Marsdiep inlet, and to protect the toe of the dykes (Schoorl, 1973; Elias \& Van der Spek, 2006). It was not until the 18th century before the continuous scouring of this updrift embankment was permanently halted by the construction of stone revetments, predecessors of what is now known as Helderse Zeewering. Similarly, smaller-scale protections were placed at the updrift island tips of the Eierlandse Gat, Vlie inlet and Ameland inlet during the last century (summarised by Cleveringa et al., 2004).

Since 1990, the Dynamic Preservation policy prescribes that the North-Sea coastlines of the barrier islands may not retreat landward of a reference line that is based on their 1990 position (Van Koningsveld \& Mulder, 2004). Coastline retreat is counterbalanced mainly by sand nourishments to mitigate structural erosion. This maintenance strategy, in combination with the island tip protections, effectively keeps the barrier islands in place.

\section{Methods}

The evolution of the western part of the Dutch Wadden Sea since the $15^{\text {th }}$ century is well documented due to the presence of harbors such as Kampen and Amsterdam and their approach channels leading through the Wadden Sea into the Zuiderzee, while the Wadden Sea behind the islands of Texel and Terschelling was a protected roadstead frequented by large sailing vessels. Nautical and hydrographical charts describing the location and depth of the main channels and shoals in the inlet system date back to the $16^{\text {th }}$ century AD (Rijzewijk, 1986). Historic reconstructions of Wadden-Sea morphology are presented by Schoorl $(1973 ; 1999 ; 2000 a, b, c)$ for the entire western Dutch Wadden Sea, by Elias \& Van der Spek (2006) for the Texel Inlet, and by 0ost (1995) for Ameland and Frisian Inlets. Detailed descriptions of the palaeogeographical evolution of the Dutch coastline are given in e.g., Beets \& Van der Spek (2000), Vos et al. (2011) and Zagwijn (1986). Basis of the present study is a series of bathymetric datasets, starting from 19251935, that are digitally available at Rijkswaterstaat (Ministry of Transport, Public Works and Water Management, now Ministry of Infrastructure and the Environment). Since 1987, these maps are collected frequently using single-beam echo sounders. The ebb-tidal deltas and basins are measured in 3-year and 6-year intervals respectively. Following quality checking for

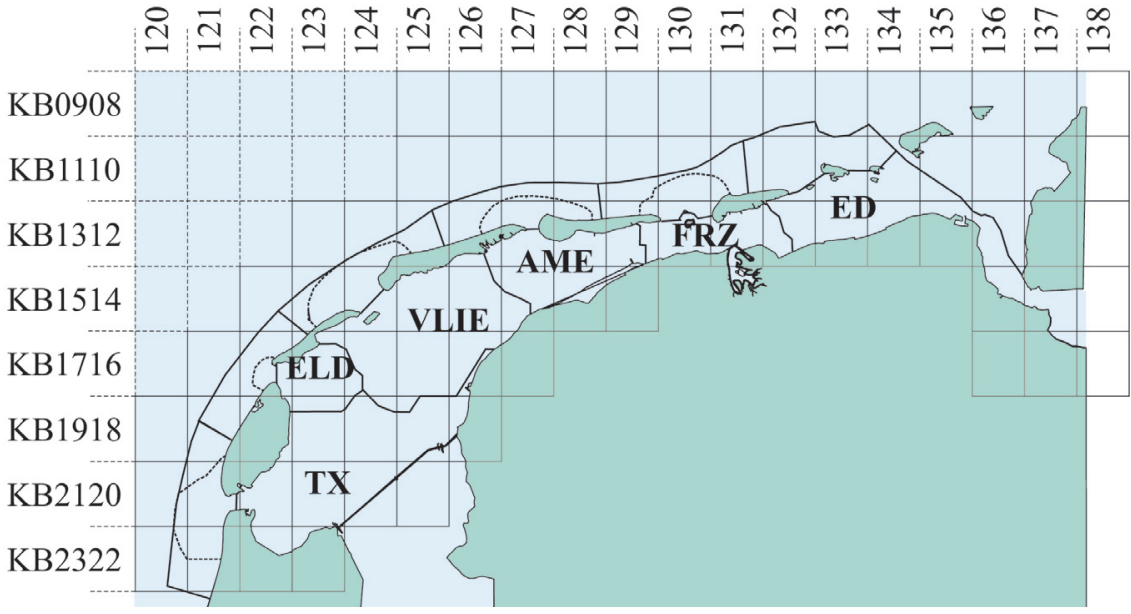

Fig. 4. Overview of the 'Vaklodingen' blocks. Inlet polygons used in the volume analysis (coast and basin) are depicted by solid lines. The ebbtidal delta (ETD) polygon by the dashed line. 

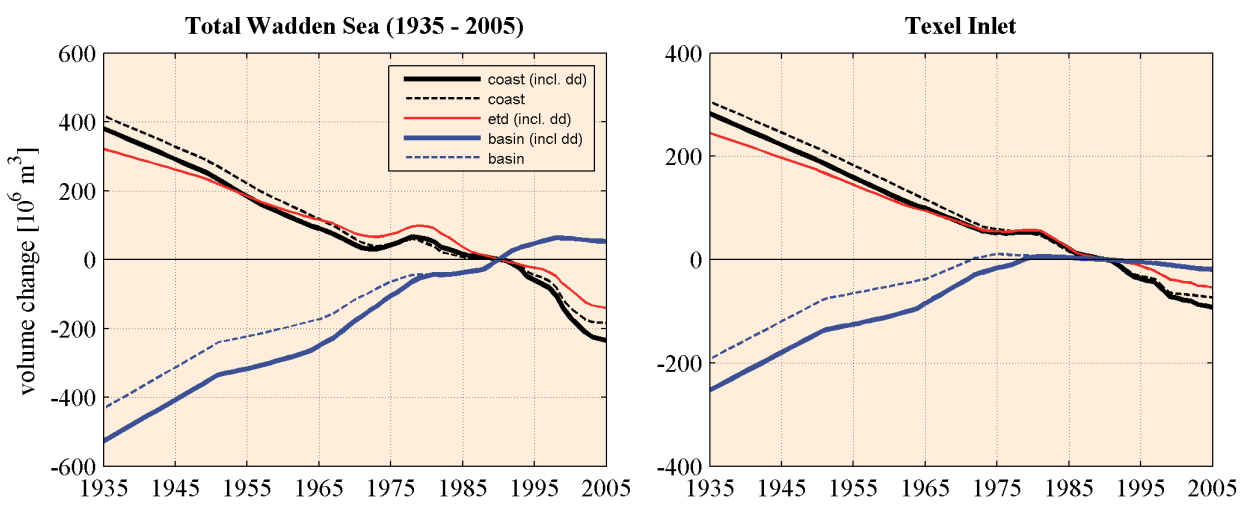

a. $b$.
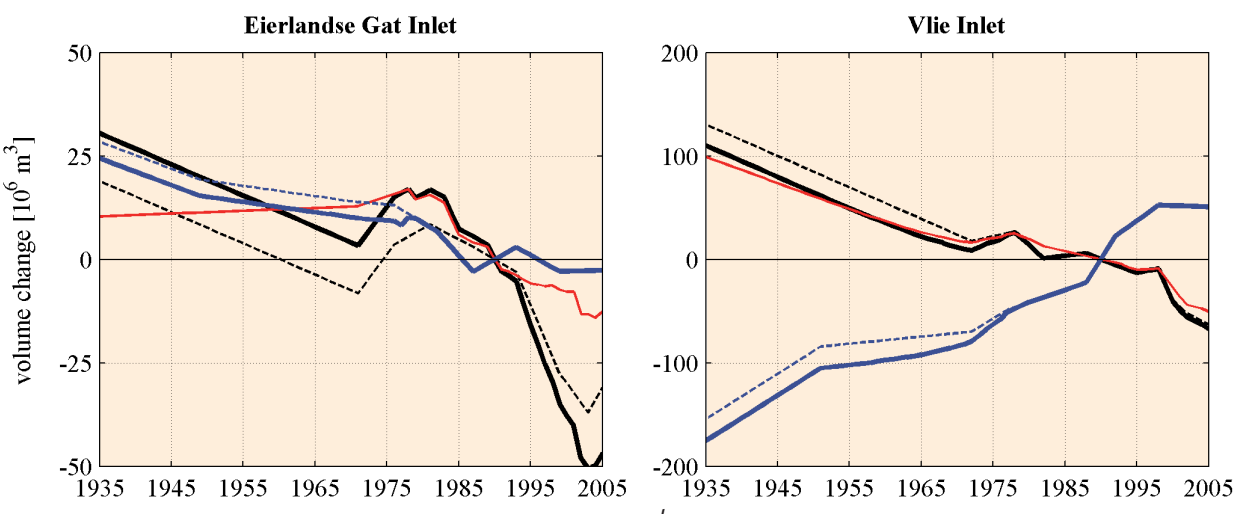

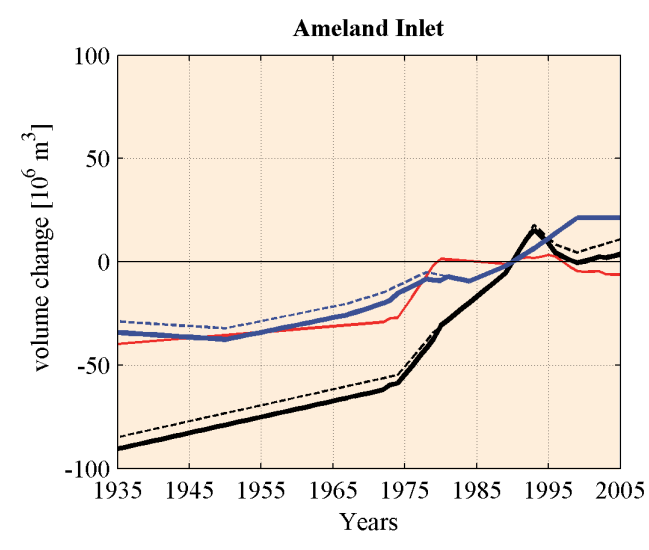

e.

measurement errors, data are combined with nearshore coastline measurements, interpolated to a $20 \times 20 \mathrm{~m}$ grid, and stored digitally as $10 \times 12.5 \mathrm{~km}$ blocks called 'Vaklodingen' (Fig. 4). Data collected prior to 1987 were originally released as paper maps and digitised in $250 \times 250 \mathrm{~m}$ resolution for the Western Wadden Sea in the 1990's. Extensive descriptions of the measurements and conversion to complete maps are documented in e.g. Rakhorst (1986), Glim et al. (1988; 1990), De Boer et al. (1991), and summarised by De Kruif (2001). Maps for the Frisian Inlet were constructed during the Coastal Genesis (Kustgenese) project and stored in approximately $90 \times 90 \mathrm{~m}$ resolution (0ost, 1995).

Changes in survey techniques and instruments, and variations in correction and registration methods during the measurements over time make it difficult to estimate the exact
Friesche Zeegat

Fig. 5. Overview of the sedimentationerosion values derived from the 'Vaklodingen' data, using the inlet and basin definition polygons, over de period 1935-2005. a. Total Wadden Sea; b. Texel Inlet; c. Eierlandse Gat Inlet; d. Vlie Inlet; e. Ameland Inlet; and f. Friesche Zeegat Inlet (Frisian Inlet).

accuracy of the maps. Wiegmann et al. (2005) and Perluka et al. (2006) estimate the vertical accuracy to range between 0.11-0.40 m. However, close scrutiny of the data showed data outliers and inconsistencies in a minor part of the dataset beyond this range. A number of steps were taken to ensure as accurate as possible estimates of the sedimentation-erosion volumes presented in this study: 1) for each 'Vaklodingen' block a sequence of raw data maps were compiled for the available years; 2) each individual map in the sequence was visually inspected and missing single data points were corrected by triangular spatial interpolation and data outliers were removed; 3) incomplete datasets were filled in using a linear interpolation between nearest in time available datasets (larger gaps) or using internal diffusion from the nearest spatial points. (smaller gaps); 4) sedimentation-erosion trends were obtained 
by subtracting subsequent measurements; and 5) the sequences of sedimentation-erosion maps were inspected and maps with unrealistic trends in basin or ebb-tidal delta changes were deleted. In total approximately $10 \%$ of all data were reanalysed and corrected or deleted.

Following construction, inspection and correction of the individual data sets, yearly maps for the period 1935-2005 were generated by linear interpolation between the available datasets. Since the yearly data are interpolated on the same grid, a straightforward subtraction of the datasets with a set starting year (1990) provides the sedimentation-erosion values (Fig. 5). The year 1990 is chosen as this is the first complete, representative map in $20 \times 20 \mathrm{~m}$ resolution, and the official starting year of the dynamic coastline preservation policy (Van Koningsveld \& Mulder, 2004). The calculated volumes were corrected per year for dredging, dumping and sand mining, based on the volumes presented in Hoogervoorst (2005), and updated with sand nourishment volumes up to present (Table 1). The most eastern part of the Dutch Wadden Sea, the Ems-Dollard estuary is not included in the sediment budget analysis due to the limited data availability.

Table 1. Nett dredge (-) and dump (+) volumes, million $m^{3}$, in the Wadden Sea inlets between 1935 and 2005.

\begin{tabular}{|c|c|c|c|c|c|c|}
\hline \multirow[t]{3}{*}{ Inlet } & \multicolumn{3}{|c|}{ Coast (million $\mathrm{m}^{3}$ ) } & \multicolumn{3}{|c|}{ Basins (million $\mathrm{m}^{3}$ ) } \\
\hline & $1935-$ & 1990- & 1935- & 1935- & 1990- & $1935-$ \\
\hline & 1990 & 2005 & 2005 & 1990 & 2005 & 2005 \\
\hline TEX & -23.8 & 20.2 & -3.8 & -60.4 & 0 & -60.5 \\
\hline ELD & 11.5 & 15.8 & 27.3 & -4.0 & 0 & -4.0 \\
\hline VLIE & -20.5 & 4.5 & -16.0 & -20.9 & -0.3 & -21.2 \\
\hline AME & -5.6 & 7.1 & 1.5 & -5.4 & -0.02 & -5.4 \\
\hline FZG & 1.3 & 3.1 & 4.4 & -3.3 & -0.08 & -3.4 \\
\hline Total & -37.1 & 50.5 & 13.4 & -94.0 & -0.4 & -94.4 \\
\hline
\end{tabular}

\section{Analyses and Results}

\section{The Dutch Wadden Sea system}

Figure 6 illustrates that on the gross scale little has changed in major inlet characteristics between the 1935 and 2005 bathymetry:

1. The six major inlets remain present, although the locations of the tidal divides separating the associated tidal basins in general shifted eastward. Similar eastward migration of tidal divides was observed in the German Wadden Sea and attributed to the predominant eastward wind direction (FitzGerald \& Penland, 1987). Additionally, changes in tidal characteristics in the individual inlets might also have contributed. Wang et al. (2011) point to the importance of the relative tidal amplitude difference between neighboring inlets for the tidal divide location. Measurements at the tidal divide behind Ameland Island provide evidence for a significant eastward residual flow due to both tides and wind (De Boer et al., 1991).

2. Each inlet still consists of similar morphodynamic elements such as large ebb-tidal deltas. This in spite of the fact that the ebb-tidal delta volumes decreased and the delta margins moved landward. These deltas are connected by single or multiple inlet channels to the basin. The channels in the basin (with the exception of Texel) form a fractal pattern.

3. The distinct difference in intertidal shoal area between the Eastern and Western Wadden Sea remains present. Only about $25 \%$ of the surface area of the back-barrier basin of Texel Inlet consists of intertidal flats as a consequence of the large tidal channels that existed here before the closure of the Zuiderzee, whereas the basins related to the Ameland and Frisian Inlets include about $50 \%$ and over $70 \%$ tidal flats, respectively. This difference can partly be explained by the difference in size of the basins (Renger \& Partenscky, 1974).

Although the gross-scale characteristics remain comparable, large volume changes and local morphological alterations have taken place. Corrected for dredging and dumping, a volume of nearly 600 million $\mathrm{m}^{3}$ of sediment accumulated in the Dutch Wadden Sea basins over the period 1935-2005, of which the largest part, over 500 million $\mathrm{m}^{3}$, between 1935 and 1990 (Table 2). The yearly sedimentation rate over this period was 9.4 million $\mathrm{m}^{3}$ per year. Roughly half of the sediments were deposited in the Texel Inlet basin (Table 3). Over the period 1990-2005 the sedimentation rate dropped to 3.6 million $\mathrm{m}^{3}$ per year. The sandy sediments were predominantly supplied by erosion of the ebb-tidal deltas, the barrier islands and the adjacent shore of North-Holland (Fig. 6). The following subsections present details on individual inlet systems.

\section{Texel and Vlie Inlet}

The morphodynamic changes in the western part of the Wadden Sea are largely dictated by adaptation to the effects of closure of the Zuiderzee (Sha, 1990; Elias et al., 2003; Elias \& Van der Spek, 2006). The closure dam Afsluitdijk reduced the Texel and Vlie basins from over $4000 \mathrm{~km}^{2}$ to roughly $1400 \mathrm{~km}^{2}$. The change in tidal characteristics from a propagating to a standing tidal wave and the greater tidal wave reflection at the closure dam drastically increased the tidal range from approximately 1.1 to $1.4 \mathrm{~m}$ at Den Helder tidal station (Rietveld, 1962; Thijsse, 1972; Elias et al., 2003). The large changes in basin hydrodynamics and geometry resulted in pronounced changes in the morphodynamic evolution of the remaining basin. Over 450 million $\mathrm{m}^{3}$ of sediment accumulated in the basins of the Texel and Vlie inlets (Table 2). Extensive sedimentation occurred in the distal parts of the former access channels to the Zuiderzee, where tidal currents reduced to almost zero and caused the channels to accrete rapidly, and on the shoal areas 


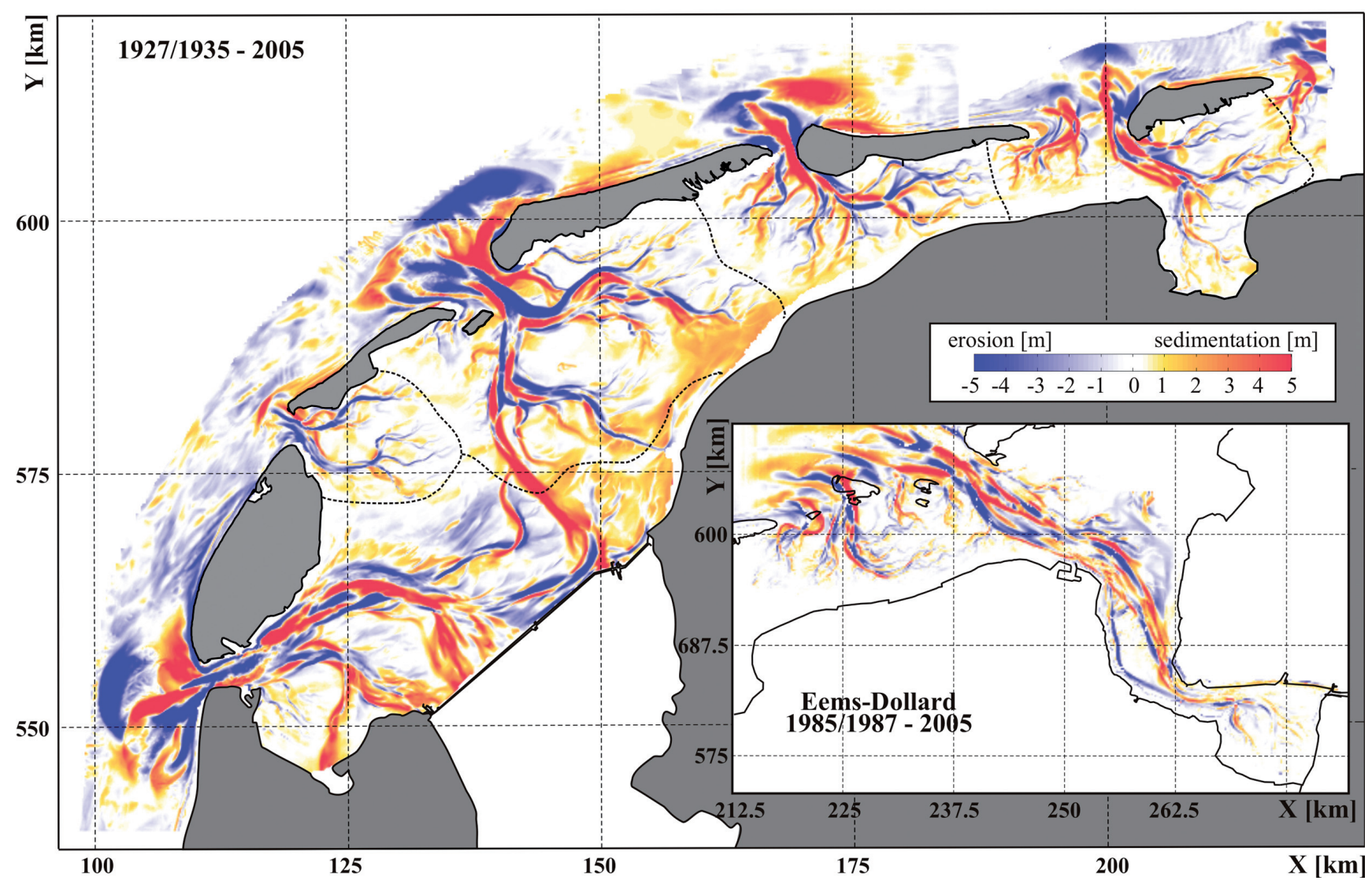

Fig. 6. Representative sedimentation-erosion map over the periods 1927/1935 till 2005. Due to data availability the Groninger Wad / Eems Dollard evolution can only be derived over the period 1985/1987 till 2005 (insert).

Table 2. Wadden Sea volume change (1935-2005) including dredge and dump volumes (+accretion, - erosion). See Fig. 4 for definition of the inlet polygons.

\begin{tabular}{|c|c|c|c|c|c|c|c|c|c|}
\hline \multirow[t]{2}{*}{ Inlet } & \multicolumn{3}{|c|}{ Coast $^{2}\left(\right.$ million $\mathrm{m}^{3}$ ) } & \multicolumn{3}{|c|}{ Ebb-tidal deltas (million $\mathrm{m}^{3}$ ) } & \multicolumn{3}{|c|}{ Basins (million $\mathrm{m}^{3}$ ) } \\
\hline & $1935-1990$ & $1990-2005$ & $1935-2005$ & $1935-1990$ & $1990-2005$ & $1935-2005$ & $1935-1990$ & $1990-2005$ & $1935-2005$ \\
\hline TEX $^{1}$ & -282.2 & -93.4 & -375.6 & -244.9 & -54.7 & -299.6 & 253.0 & -19.1 & 233.9 \\
\hline ELD & -30.5 & -46.8 & -77.3 & -10.4 & -12.7 & -23.0 & -24.4 & -2.7 & -27.1 \\
\hline VLIE & -110.0 & -36.3 & -146.3 & -99.1 & -26.3 & -125.4 & 166.5 & 52.7 & 219.2 \\
\hline AME & 90.5 & 3.7 & 94.2 & 39.8 & -6.1 & 33.7 & 34.2 & 21.4 & 55.6 \\
\hline FZG & -48.4 & -31.7 & -80.1 & -6.1 & -17.1 & -23.2 & 88.5 & 2.4 & 90.9 \\
\hline Total & -380.6 & -204.5 & -585.1 & -320.7 & -116.9 & -437.5 & 517.8 & 54.7 & 572.5 \\
\hline
\end{tabular}

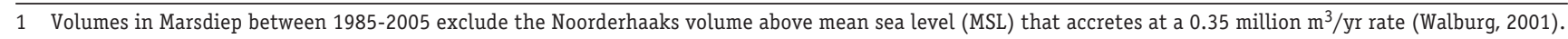

2 Coast volumes include the ebb deltas.

Table 3. Sediment budgets ebb-tidal delta - basin (1935-2005), based on the volume changes presented in Table 2, sediment budgets per year and average yearly vertical changes for the tidal basins of the Dutch Wadden Sea.

\begin{tabular}{|c|c|c|c|c|c|c|c|c|c|}
\hline \multirow[t]{2}{*}{ Inlet } & \multicolumn{3}{|c|}{$\begin{array}{l}\text { Sediment balance ebb-tidal } \\
\text { delta - basin }{ }^{1}\left(\text { million } \mathrm{m}^{3} \text { ) }\right.\end{array}$} & \multicolumn{3}{|c|}{$\begin{array}{l}\text { Sediment balance per year } \\
\left(\text { million } \mathrm{m}^{3}\right)\end{array}$} & \multicolumn{3}{|c|}{$\begin{array}{l}\text { Vertical change in basins per year }{ }^{2} \\
(\mathrm{~mm})\end{array}$} \\
\hline & 1935-1990 & 1990-2005 & $1935-2005$ & $1935-1990$ & 1990-2005 & $1935-2005$ & $1935-1990$ & $1990-2005$ & $1935-2005$ \\
\hline TEX & 8 & -74 & -66 & 0.1 & -4.9 & -0.9 & 6.46 & -1.79 & 4.69 \\
\hline ELD & -35 & -15 & -50 & -0.6 & -1 & -0.7 & -2.9 & -1.18 & -2.53 \\
\hline VLIE & 67 & 26 & 94 & 1.2 & 1.8 & 1.3 & 4.53 & 5.26 & 4.69 \\
\hline AME & 74 & 15 & 89 & 1.3 & 1 & 1.3 & 2.01 & 4.62 & 2.57 \\
\hline FZG & 82 & -15 & 68 & 1.5 & -1 & 1 & 8.25 & 0.82 & 6.66 \\
\hline Total & 197 & -63 & 135 & 3.6 & -4.1 & 2.0 & 4.62 & 1.79 & 4.02 \\
\hline
\end{tabular}

1 NB: A positive balance means deposited volume in basin is larger than eroded volume on ebb-tidal delta.

2 See Fig. 1 for basin surface areas (MHW). 

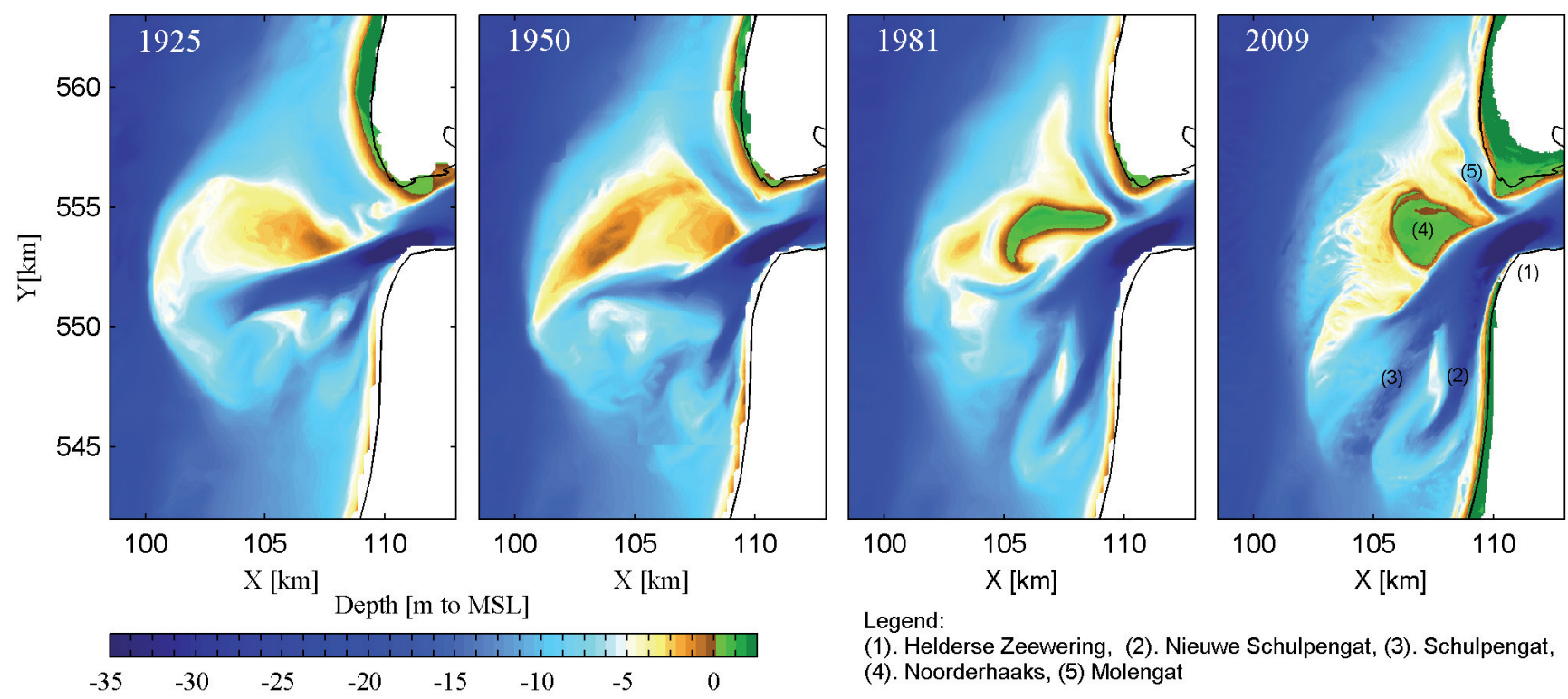

Legend:

(1). Helderse Zeewering, (2). Nieuwe Schulpengat, (3). Schulpengat, (4). Noorderhaaks, (5) Molengat

Fig. 7. Details of the Texel Inlet ebb-tidal delta bathymetry for the representative years 1925, 1950, 1981 and 2009. The maps shows a landward retreat of the ebb-tidal delta and scouring of large tidal channels along the adjacent coasts.
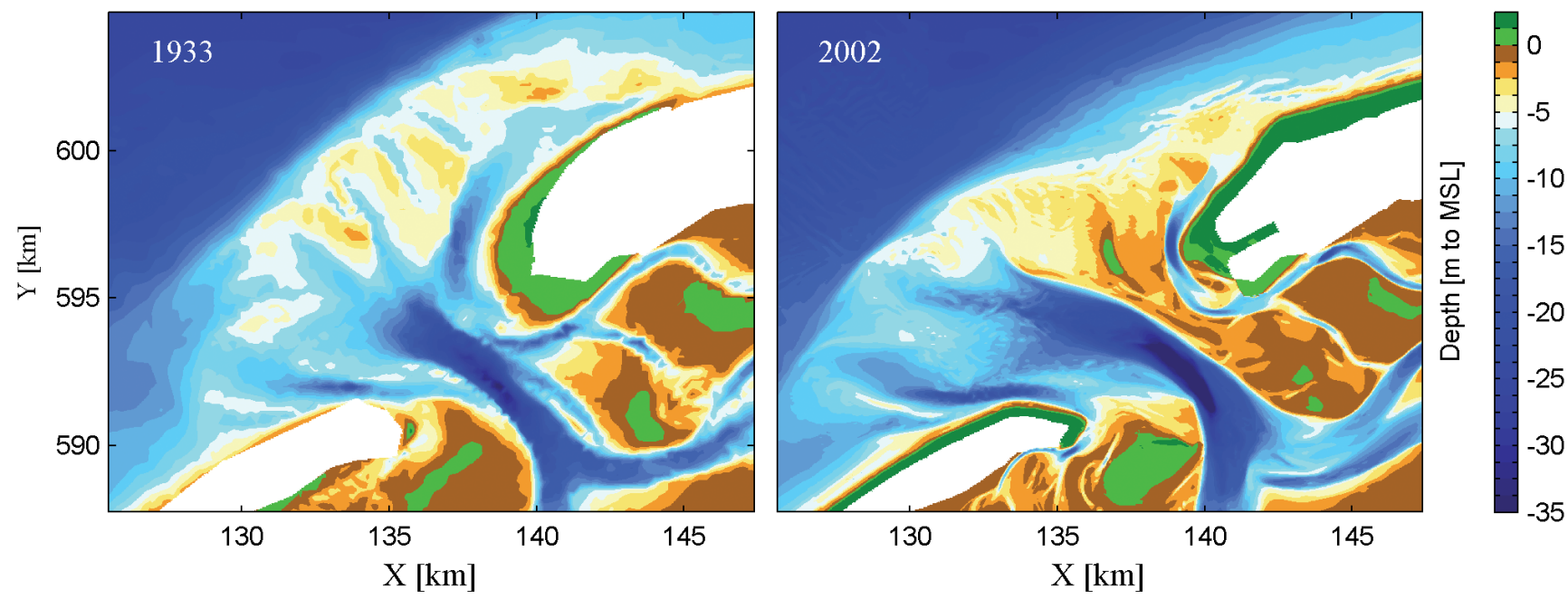

Fig. 8. Details of the Vlie Inlet for the representative years 1933 and 2002. Maps illustrate channel scouring on the downdrift side and shoal formation updrift.

along the Frisian coast (Fig. 6). Berger et al. (1987) showed that much of the initial infill of the closed-off channels consists of alternating layers of more sandy and more muddy sediments. The accumulation of fine-grained sediment might explain the observed discrepancy between the larger basin-infilling rates compared to the ebb-tidal delta and coastal erosion (predominantly sand) after the closure.

Nearly 300 million $\mathrm{m}^{3}$ of sand was eroded from the Texel ebb-tidal delta and adjacent coasts (Fig. 5 and 6). A major part of the eroded volume (130 million $\mathrm{m}^{3}$ ) was delivered by the erosion of the ebb-tidal delta margin, and scouring of large tidal channels in a southward direction (Elias et al., 2003; Elias \& Van der Spek, 2006). The stable position of the inlet channel is due to Helderse Zeewering (a stone seawall protecting the tip of North Holland). The closure induced relocation of the main tidal channels on the ebb-tidal delta Schulpengat and Nieuwe
Schulpengat, and the northward and southward outbuilding of the ebb-tidal delta, took about 40 years to complete. The changes in ebb-tidal delta morphology had large consequences for the coastal maintenance of the adjacent coastal sections (Fig. 7). Major erosion was encountered at the location of the new main channels $\left(70\right.$ million $\mathrm{m}^{3}$ ) and the adjacent coastal sections structurally retreated. The erosion and coastline retreat result from the presence of the large nearshore tidal channels. These channels capture a large amount of the littoral drift, limiting sediment bypassing and beach recovery (Elias \& Van der Spek, 2006). Maintenance of the stretches of coast along Texel Inlet belongs to the most intensive of the entire Dutch coastal system (Roelse, 2002; Cleveringa et al., 2004; Hoogervoorst, 2005). In contrast to the updrift relocation of the main channels, the main shoal area to the northwest of these channels predominantly migrated landward, increasing the height of the Noorderhaaks 
shoal (Fig. 7), and forming a large northward (downdrift) spit. The wave-driven landward movement of this spit forces the flood-dominated Molengat channel against the Texel coast. This contributes to the structural erosion of this part of the island. An exception is the utmost southern island tip 'the Hors' which increases in size (Ballarini et al., 2003). Increased wavedriven transports on the higher shoals and the presence of large tidal channels allows for efficient sediment transport into the basin. This explains the continued high sediment import rates.

A linear erosion trend with erosion rates of 2 million $\mathrm{m}^{3} / \mathrm{yr}$ (Table 2) dominated the Vlie ebb-tidal delta up to 2005 (Fig. 5). Prior to the closure of the Zuiderzee, Vlie Inlet consisted of a centrally located main ebb channel and two smaller flood channels along the island shores (Fig. 8). The ebb-tidal delta extended $10 \mathrm{~km}$ seaward and roughly 10 and $15 \mathrm{~km}$ along the Vlieland and Terschelling coasts, respectively. The bulk of the ebb-tidal delta deposits was located north (downdrift) of the main ebb channel. Analysis of historic maps (Joustra, 1973) points to 'outer channel shifting' as main sediment bypassing mechanism (see FitzGerald et al., 2000 for a mechanism description). The sequence of shoals and smaller channels on top of the downdrift ebb-tidal delta platform illustrates various stages of the bypassing sequence (see Figure 8, 1933 bathymetry). These shoals migrate northward and eventually merge with the Terschelling coast roughly fifteen kilometres downdrift of the inlet. Large morphodynamic changes are observed on the ebb-tidal delta since the closure of the Zuiderzee (Fig. 8). The central part of the inlet remained stable in position, the distal part of the main ebb channel rotated in a more updrift direction, increasing in size and depth. This updrift rotation disrupted the outer-channel shifting mechanism for sediment bypassing. The sediment-starved downdrift part of the ebb-tidal delta rapidly migrated onshore and increased in height. In the period 1933-2002 the shoal area (roughly bounded by the $15 \mathrm{~m}$ depth contour) decreased from $140 \mathrm{~km}^{2}$ to $112 \mathrm{~km}^{2}$, a reduction of $20 \%$. The smaller flood-dominant channel extending along the northwestern tip of Terschelling, prevented the ebb-tidal delta shoals to directly attach and merge with the coastline. Approximately $10 \mathrm{~km}$ updrift of the inlet, accretion prevailed as the relic shoal complexes attached and merged with the Vlieland coastline. At the island tip severe erosion occurred due to the landward migration and increasing depth of the marginal flood channel.

The notably smaller erosion values of the Vlie ebb-tidal delta since 1935 (2 million $\mathrm{m}^{3} / \mathrm{yr}$ ), compared to the observed sedimentation in its tidal basin ( 3 million $\mathrm{m}^{3} / \mathrm{yr}$ ), render it likely that much of the deposited sediments are supplied by the Texel Inlet system. The two inlet systems are coupled and cannot be analysed separately.

\section{Eierlandse Gat Inlet}

With a basin surface area of $153 \mathrm{~km}^{2}$ Eierlandse Gat Inlet is only a small system compared to Texel Inlet and Vlie Inlet. Nonetheless, continuous erosion of the updrift Texel coastline has made the inlet one of the most nourished systems along

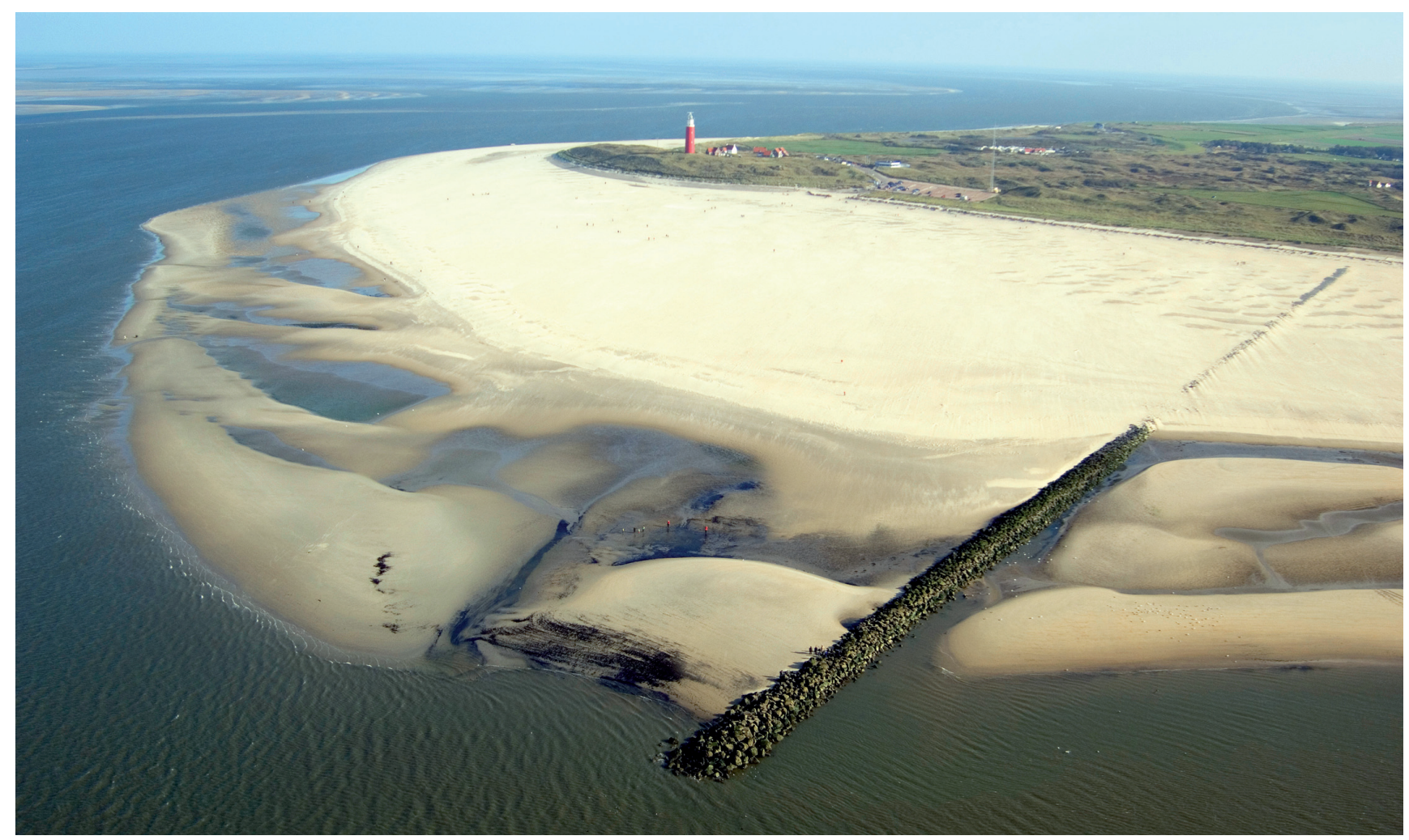

Fig. 9. Accretion around the Eierlandse Gat dam in 2005 (source: https://beeldbank.rws.nl, Rijkswaterstaat). 
the Dutch Wadden Sea, with nourishments starting as early as in 1979. Despite these nourishments, the inlet has a negative sediment budget since 1935 (Table 2), with a strong erosion of $2.9 \mathrm{~mm}$ per year averaged over the basin between 1935 and 1990. This erosion is likely related to the hydraulic changes caused by the closure of the Zuiderzee. The erosion of Texel Island must have been increased by the latter, although the islands coastline retreat has been an ongoing process since the separate islands of Texel and Eierland were connected by construction of a sand dyke in 1629 (Schoorl, 2000a). This sediment loss is attributed to the strong curvature of the islands coastline that causes a divergence in the longshore sediment transports (Rakhorst, 1999). At the island tips, migrating channels periodically induce severe erosion as channels scour and sediment supply by ebb-currents fluctuate with channel orientations and positions.

A long history of erosion control measures exists. The major interventions are the reinforcement of the island tips with stone seawall-groin systems in 1948 and 1956. These structures were effective in keeping the island tips in place, but severe updrift coastal erosion continued, making periodic nourishments necessary. Between 1979 and 1995 over 11 million $\mathrm{m}^{3}$ of sand was placed on the updrift beaches (Hoogervoorst, 2005). An $800 \mathrm{~m}$ long shore-normal stone dam constructed in 1995 just south of the inlet reduced maintenance nourishments drastically from 660,000 to $270,000 \mathrm{~m}^{3} / \mathrm{yr}$ (De Kok, 2005), and a wide beach accreted just south and north of the dam (Fig. 9). The Eierlandse Gat Dam shows that a strategically placed hard construction can (at least temporarily) help mitigate island tip erosion. However, since 2008 the Texel coastline is eroding severely again 1 to $2 \mathrm{~km}$ south of the dam. A point of concern is the present development and attachment of the inlet channel to the scour hole at the tip of the dam, possibly changing the inlet channel dynamics and undermining the dam and island tip stability.

\section{Ameland Inlet}

Cyclic development of channel and shoal patterns governs the bathymetric changes of Ameland Inlet (Van der Spek \& Noorbergen, 1992; Israel \& Dunsbergen, 1999; Cleveringa et al. 2005; Cheung et al., 2007). Based on the analysis of historic datasets (early $19^{\text {th }}$ century - 1997), these authors point to a cyclic evolution of the channels and shoals on the ebb-tidal delta with a period of 50 to 60 year. The stage within this cycle determines whether erosion or sedimentation occurs along the adjacent island tips. The morphodynamic evolution between 1933 and 2005 includes sediment redistribution from the updrift to the downdrift part (Fig. 10). By 1989 the channel had split into a two-channel system with the main channel hugging the western end of Ameland, inducing severe local erosion and restoring the necessity of hard and soft maintenance efforts. Erosion control measures have been frequently applied since
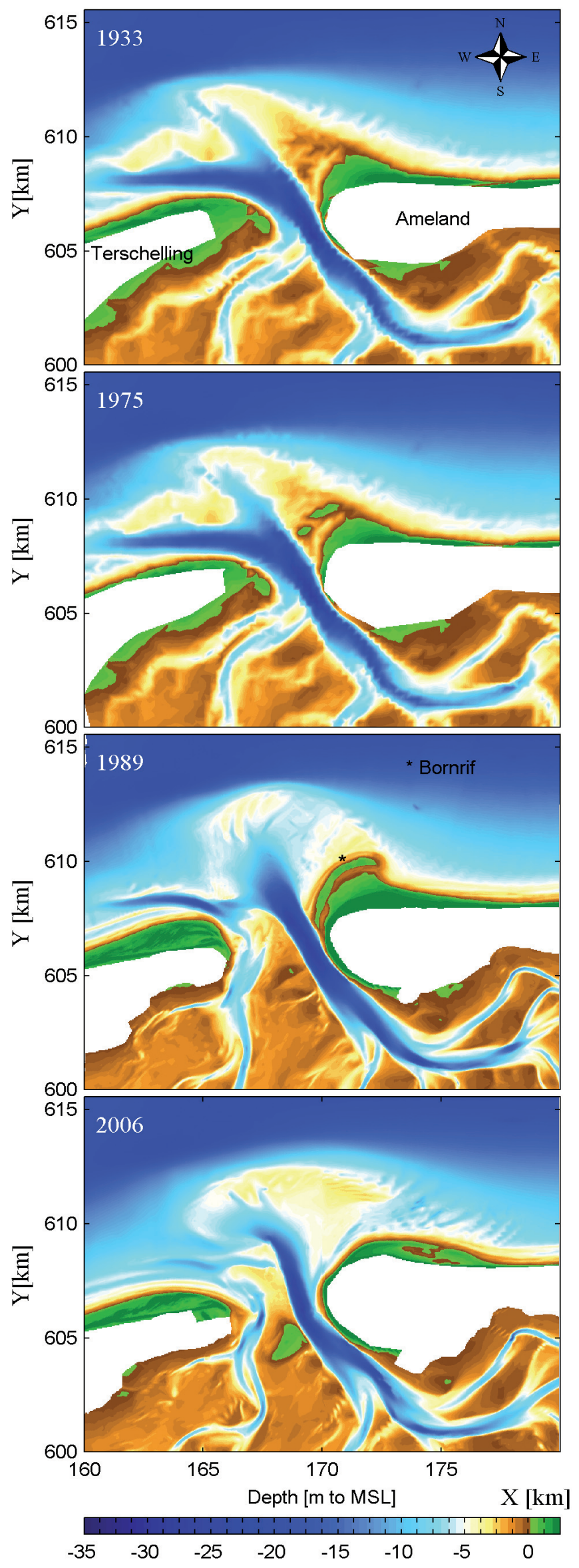

Fig. 10. Cyclic developments of the Ameland ebb-tidal delta. 
the 1940's. The first stone revetments were placed in 1947, followed in 1979 by an along-shore stone dam and groin system and periodic sand nourishments of the island. These nourishments continue till present day.

At the Ameland coastline, a large wave-built bar migrated onshore and formed a spit system called Bornrif (Fig. 10). Bornrif attached to the coast between 1968 and 1998, temporary inducing substantial local erosion and accretion. Presently, a marginal channel appears to have developed again at the former location of Bornrif, while the Bornrif sediment is redistributed eastward as a spit along the coast of Ameland by littoral drift (Fig. 10). The basin is governed by sediment deposition (56 million $\mathrm{m}^{3}$ between 1935 and 2005) and channelshoal migration (Fig. 10; 1927 and 1975). Sediments are likely supplied by Vlie Inlet as deposition primarily occurs near the Vlie-Ameland tidal divide (Elias, 2006). The changed hydrodynamics in the Western Wadden Sea after the closure of the Zuiderzee might have contributed to the eastward displacement of the Ameland tidal divide. Migration of the Terschelling tidal divide has been an ongoing long-term trend related to the earlier siltation of the Middelzee estuary around $1300 \mathrm{AD}$ (Van der Spek, 1995).

\section{Frisian Inlet}

The supra-tidal shoal (Engelmansplaat) separates the two main inlet channels Pinkegat and Zoutkamperlaag that form the Frisian inlet and share a common ebb-tidal delta (Fig. 11). Before the closure of the Lauwerszee in 1969, both Pinkegat and Zoutkamperlaag displayed a cyclic alteration between single and double channel configurations (Biegel, 1993; 0ost, 1995). Similar to the effects of the Zuiderzee closure, the Frisian Inlet underwent significant morphodynamic changes such as increased infilling of the basin and eastward realignment of the basin channel in response to closure of the Lauwerszee. Upon the completion of the closure dam in 1969, approximately $30 \%$ of the surface area of the former basin was dammed off. The closure caused a considerable reduction in tidal prism from 306 million $\mathrm{m}^{3}$ to 200 million $\mathrm{m}^{3}$, which induced major morphological changes both in the basin and at the ebb-tidal delta as the inlet started to evolve to a new state of dynamic equilibrium. The pre-closure ebb-tidal delta size and the originally seaward extending main channel could not be maintained by the reduced tidal currents. Wave-driven onshore transports induced erosion especially on the ebb-tidal delta front, contributing to sediment transport onto the coast and into the inlet channel and backbarrier basin. Initially, the ebb-tidal delta volume did not change drastically as much sediment was retained by formation of a large curved bar downdrift of the main channel (see situation 1989 in Fig. 11) that finally attached to the coast. The infilling of the back-barrier basin was augmented by the deposition of large volumes of mud in the Zoutkamperlaag channel (0ost, 1995; Van Ledden, 2003, chapter. 6)
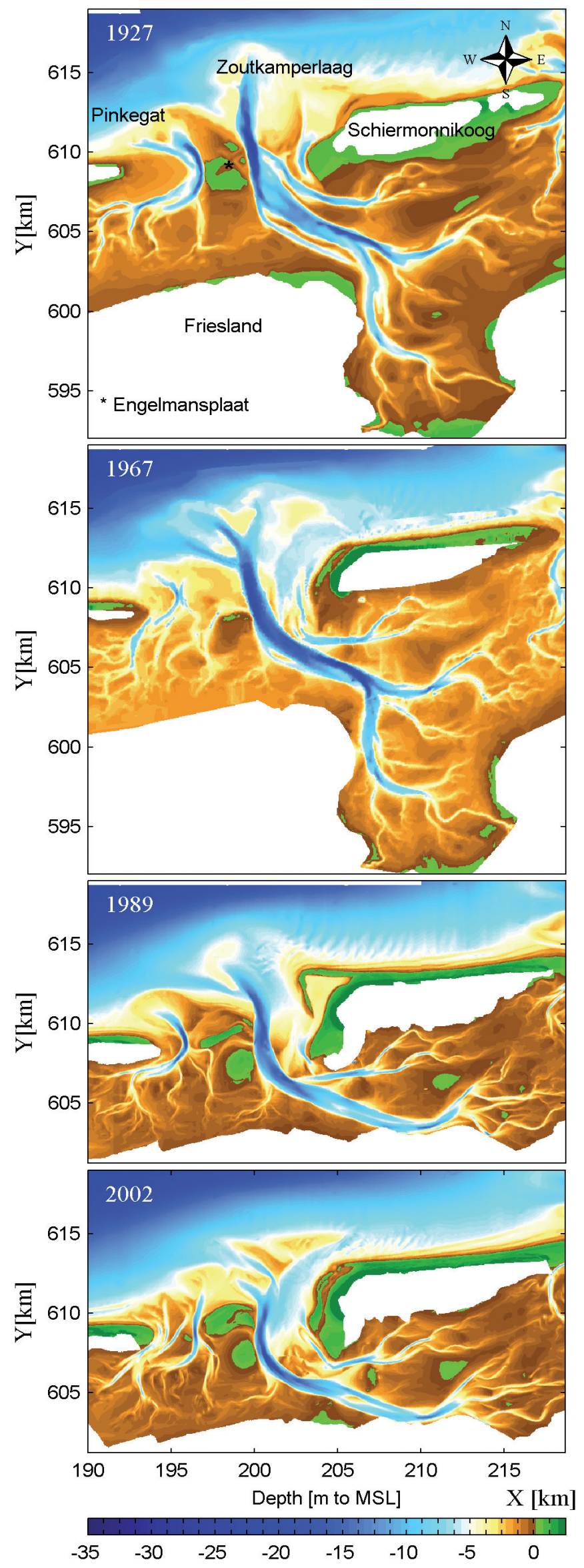

Fig. 11. Detailed development of Frisian Inlet 1927-2002. 
The Pinkegat channel shows a cyclic development from a single main channel to multiple channels and back (Van der Spek \& Noorbergen, 1992; 0ost, 1995). Cycle lengths historically varied between 20 to 40 years. After the closure, cyclic developments continued. The years 1927 and 1989 in Fig. 11 illustrate a single channel configuration (phase 1 of the cycle). The single channel migrates to the east due to the net eastward littoral drift and sand accumulation at the island tip. A multiple channel system is formed by breaching of these spit deposits (Fig. 11, 1967). The steeper hydraulic gradient between basin and sea favors the development of shorter channels by breaching of the spit, leading to abandonment of the initial main channel (Van Veen, 1936). Figure 11 illustrates a mid-cycle morphology with 2 major channels in 2002. The above described cycle length between 1927 and 1989 might be related to effects of the closure. Since 1989 a second cycle with a shorter period can be observed with an expected length of 20 to 30 years.

Prior to closure of the Lauwerszee, basin and inlet portions of Zoutkamperlaag were fairly stable in depth and position (Fig. 11, 1927-1967). On the ebb-tidal delta, the distal part of the channel and neighboring shoals exhibited periodic eastward migration, and westward realignment as hydraulic efficiency decreased. The wave-driven shoal migration pushed the channels landward, causing them to become increasingly curved and inefficient, and finally leading to total abandonment. The shoals eventually attached to and merged with the Schiermonnikoog coastline. Intervals of erosion and sedimentation dominate the coastline depending on the stage of bar development versus channel development. After the closure, the reduction in tidal prism induced morphological changes that were governed by reworking of the excess volume of ebb-tidal delta deposits. An abundant wave-driven supply of ebb-tidal delta sand formed a large curved bar complex which migrated towards, and finally merged with the island coast. Initially, the shoal merger increased the sand volume and expanded the Schiermonnikoog island tip seaward and basinward, but nowadays severe erosion prevails as the merged deposits are being reworked. After the closure, migration of the Zoutkamperlaag was not observed. The central part of the channel remained in position, with the distal part oriented updrift. The channel however reduced considerably in size and seaward extent. It is likely that the shoal complex that forms updrift of the channel will eventually initiate a cyclic development as observed prior to the closure. Erosion of the western end of Schiermonnikoog Island is expected to prevail until a new shoal attaches and merges to the coastline. The smaller ebb-tidal delta renders it likely that shoals of smaller volume will attach and merge closer to the inlet.

In the basin, increased sedimentation caused deposition of nearly 70 million $\mathrm{m}^{3}$ of sediments between 1969 and 1985. As a result the average sedimentation rate over the period 19351990 reached an average value of $8.25 \mathrm{~mm}$ per year, the highest rate of all basins in the Dutch Wadden Sea (Table 3). Most of these sediments accumulated at the closed-off entrance channel to the Lauwerszee, partly filling in the channel, see Oost (1995) en Van Ledden (2003). The channel also aligned and extended eastward along the closure dam. This eastward channel extension, together with changes in tidal wave propagation, shifted the hydrodynamic and morphologic tidal divide 3-4 km to the east between 1979 and 1987 (0ost, 1995). Since 1985 the sedimentation rates in the basin are comparable to the pre-closure rates, indicating that the major part of the morphological adaptation was completed.

\section{Groninger Wad and Ems-Dollard}

To the east of the Frisian Inlet, between the island of Schiermonnikoog and the Ems-Dollard estuary, several smallscale inlets (see Fig. 1 from west to east: Eilanderbalg, Lauwers and Schildt) are bounding the small, uninhabited barrier islands Rottumerplaat and Rottumeroog. For a large part the historic evolution of the Ems-Dollard, a combination of the Ems estuary and a connected tidal basin, the Dollard, determined the morphodynamic response of the area. The Ems-Dollard estuary reached its maximum extent around 1520, after rapid expansion of a tributary of the Ems which created the Dollard tidal basin. Natural sedimentation and land reclamation have reduced the size of the estuary ever since. In the Dollard tidal basin, land reclamation occurred till the 1950's. The channels of the EmsDollard have remained stable in position, partly due to dredging since the 1920's. From the 1960's onwards, large-scale dredging, canalisation and channel deepening formed a one main-channel system and considerably altered the tidal characteristics (larger tidal prisms, tidal asymmetry and velocities), while dumping of the dredge material increased fine-sediment concentrations (Boon et al., 2002; Cleveringa, 2008). In terms of sediment budget, dredging (roughly 10 million $\mathrm{m}^{3} / \mathrm{yr}$ ) has limited effect on the total volume of Ems-Dollard, as dredged material is dumped back into the system.

On the Groninger Wad volume changes are relative small. Most pronounced changes are the eastward expansion of Schiermonnikoog and the associated migration of the Eilanderbalg and Lauwers Inlet (Fig. 6). The eastward migrating Lauwers Inlet has become the dominant basin, taking over basin area from Schildt due to the continuous eastward expansion. The eastward expansion of Zoutkamperlaag captured some of the Eilanderbalg basin after closure of the Lauwerszee in 1969, see Fig. 11.

A detailed sediment budget and morphological analysis for the Ems-Dollard estuary and Groninger wad is presented in Cleveringa et al. (2008). The average sediment accumulation in the Ems-Dollard estuary was estimated at 4.7 million $\mathrm{m}^{3} / \mathrm{yr}$ over the period 1985-2002 (no older data are available). Erosion prevailed in the Ems mouth $\left(-10\right.$ million $\left.\mathrm{m}^{3}\right)$. Average sediment accumulation in the Groninger Wad was estimated at 0.09 million $\mathrm{m}^{3} / \mathrm{yr}$. The sediment budget is influenced by the 
significant land subsidence caused by gas extraction from the Slochteren gas field, one of the largest gas fields in the world, which affects both the Groninger Wad and the Ems-Dollard estuary. The extra volume created by subsidence was apparently instantaneously filled with sediment since no morphological changes other than those caused by normal hydraulic processes were observed. The volume increase is estimated at ca 26 million $\mathrm{m}^{3}$ between 960 and 2003 (Vonhögen, personal communication).

\section{Summary of the observed developments}

On a time scale of decades to centuries the development of the individual inlet systems is governed by (partial) basin infilling and artificial closures: Lauwerszee (Frisian Inlet) and Zuiderzee (Vlie Inlet and Texel Inlet). After closure of the Lauwerszee, Frisian Inlet obtained a new, similar, equilibrium state with reduced ebb-tidal delta that is connected by one or multiple main inlet channels to a fractal, eastward curving pattern of channels in the basin. Ratios of intertidal area versus total surface area vary between 0.6 and 0.8 . The large-scale closure of the Zuiderzee dominated the morphological evolution of the Western Wadden Sea as over 400 million $\mathrm{m}^{3}$ of sediment accumulated in the Western Wadden Sea. The near similar erosion of the adjacent coasts indicates that the majority of the sediment deposition in the basin is fed by sand supply from the adjacent North Holland coast, barrier island coasts and in particular the ebb-tidal deltas. An analysis of all major ebb-tidal delta systems in the Dutch Wadden Sea illustrates a landward retreat of the outer rim of the deltas and rapidly diminishing volumes. The observed updrift rotation of the main ebb-tidal delta channels is identified as a common and important factor. Ebb-tidal delta volume and shape are known to relate to the forcing conditions and ebb shoals are formed where supply of sediment by the ebb-tidal currents and landward wave-driven transports are balanced. Updrift rotation of the main ebb channel disrupts this balance and new updrift-located shoals are formed. The relic shoal deposits are rapidly reworked by abundant wave energy and are transported landward, into the basin and onto the adjacent downdrift coasts, at least temporarily relieving erosion stresses.

\section{Discussion and Concluding remarks}

\section{Discussion}

This sediment budget study indicates that over the period 1935-2005 an abundant sediment supply, primarily by eroding ebb-tidal deltas, has so far delivered sufficient sediment to increase the sediment volume in the Dutch Wadden Sea with about 600 million $\mathrm{m}^{3}$. This concerns the deposition of both sand and mud. The sedimentation is triggered by several developments, the most obvious development being the morphodynamic adaptation of the system to anthropogenic action such as caused by e.g. the large-scale closures of Zuiderzee and Lauwerszee. Additionally, sea-level rise and subsidence due to gas extraction must have played a role. Measurements of sea levels in the Dutch Wadden Sea illustrate an average rise of $2 \mathrm{~mm}$ per year over the last 70 years (Fig. 2). Expected morphological adaptation to sea-level rise such as an increase in tidal-flat level, are not clear from the bathymetrical changes. This is probably caused by inaccuracies in the surveying techniques, especially in the measurements from the early $20^{\text {th }}$ century. Complete compensation of this sea-level rise of $0.14 \mathrm{~m}$ would have taken a sediment volume of ca 280 million $\mathrm{m}^{3}$ (total basin surface area of $2000 \mathrm{~km}^{3}$, see Fig. 2). However, the largest part (nearly $75 \%$ ) of the volume change occurs in the Western Wadden Sea where the influence of human intervention is dominant and the large infilling rates in closed-off channels, and along the basin shoreline (see Fig. 6), rather than a gradual increase in channel flat heights, render it likely that this sedimentation is primarily a response to the closure of Zuiderzee and not an adaptation to sea-level rise.

Subsidence due to, amongst other things, gas extraction in the basins of Vlie Inlet, Frisian Inlet and at the Groninger Wad and Ems-Dollard, will have created an extra increase in water volume in the tidal basins and along the North Sea coast of Ameland. This increase is estimated at 38 million $\mathrm{m}^{3}$ over the period 1980-2003 for the Dutch Wadden Sea (Vonhögen, personal communication). However, since no morphological changes of the sea bed have been observed in the areas of subsidence, we assume that this increase in space has instantaneously been filled in with imported sand. This adds an extra $7 \%$ to the calculated volume of sedimentation.

Despite major sedimentation, the large difference in intertidal shoal to basin area ratios between the Western (0.3-0.4) and the Eastern Wadden Sea (0.6-0.8) might be an indication of the disequilibrium in the Western Wadden Sea, given that a similar forcing regime exists. Assuming that the eastern Wadden Sea is in or close to equilibrium, a large volume of sediment is needed to obtain a 0.6-0.8 intertidal shoal to basin area ratio in the Western Wadden Sea. If we assume a hypsometry similar to the Eastern Wadden Sea then 900 million $\mathrm{m}^{3}$ of sediments are needed. It is however questionable whether such hypsometry fits the present tidal characteristics of Marsdiep with its long and deep basin. Wang et al. (2011) estimates, starting from basic empirical relations for inter-tidal flat area and height (Renger \& Partenscky, 1974; Eysink \& Biegel, 1993), that in worst case the sediment demand of the Western Wadden Sea exceeds 1.5 billion m3. Accelerated sea-level rise makes this equilibrium channel-shoal ratio even harder to reach.

In recent history, numerous smaller-scale coastal interventions have been performed in and around the Wadden Sea. To prevent flooding of the hinterland most of the basin coastline was stabilised with dykes and salt-marsh formation was stimulated with small-scale engineering works. On the barriers, 
island tip protections such as groins and sea-walls and since 1990 sand nourishments were used to counteract erosion. Locally, these erosion-control measures have certainly been successful in retaining the shoreline positions. However, the cumulative effect of numerous small-scale interventions might also have impacted the long-term behavior of the Wadden Sea. As the basin and barrier dimensions are basically fixed in position, the effects of sea-level rise now have to be resolved within the fixed dimensions of the Wadden Sea. The historically observed roll-over mechanisms of landward barrier and coastline retreat (Van Straaten, 1975; Flemming \& Davis, 1994; Van der Spek, 1994) cannot be sustained naturally. It is unlikely that the sediments needed to regain equilibrium can be delivered by the remaining ebb-tidal deltas. Unless sufficient sediment is delivered to let the system accrete in place, permanent drowning of large parts of the intertidal basin is to be expected. Besides, it is uncertain whether sediment transport capacity in the inlets is sufficient.

\section{Implications for the future}

The Wadden Sea is considered to be one of the last large tidal regions where natural forces have free reign without a dominating influence from human activities. However, for sustainable management of the Wadden Sea system in the future it is important to recognise that natural processes can now only reign free within fixed boundaries. Multiple large- and smallscale interventions have basically fixed the basin and barrier dimensions. On the gross scale, the Wadden Sea has proven resilient to these interventions and sea-level rise, as only little has changed in main inlet and basin characteristics between the 1925 and 2005 bathymetry. The large continuous sedimentation in the tidal basins (over 600 million $\mathrm{m}^{3}$ ) and similar inlet and channel-shoal characteristics seem to indicate that the Wadden Sea can import sediment exceeding the present rates of relative sea-level rise given sufficient sediment supply. A major constraint however is future sediment availability. At present much of the basin infilling is supplied by the ebb-tidal deltas (Texel Inlet in particular) that are limited in size and rapidly reducing in volume. Increased coastal and barrierisland erosion is to be expected. Repeated beach and shoreface nourishment and optional ebb-tidal delta nourishment to mitigate erosion, adding to the sediment budget of both islands and basins, might be used to sustain sufficient sediment availability, allowing the natural system to respond to future sea-level rise. Without future human intervention it is unlikely that the adjacent barriers and coasts can supply sufficient sediment to regain and keep the Wadden Sea in dynamic equilibrium to relative sea-level rise.

\section{References}

Baart, F., Van Gelder, P.H.A.J.M., De Ronde, J., Van Koningsveld, M. \& Wouters, B., 2012. The Effect of the 18.6-Year Lunar Nodal Cycle on Regional Sea-Level Rise Estimates. Journal of Coastal Research 28(2): 511-516.

Ballarini, M., Wallinga, J., Murray, A.S., Van Heteren, S., Oost, A.P., Bos, A.J.J. \& Van Eijk, C.W.E., 2003. Optical dating of young coastal dunes on a decadal time scale. Quaternay Science Reviews 22 (10-13): 1011-1017.

Bartholdy, A.T., Bartholdy, J. \& Kroon, A., 2010. Salt marsh stability and patterns of sedimentation across a backbarrier platform. Marine Geology 278: 31-42.

Bartholomä, A. \& Flemming, B.W., 2007. Progressive grain-size sorting along an intertidal energy gradient. Sedimentary Geology 202: 464-472.

Beets, D.J. \& Van der Spek, A.J.F., 2000. The Holocene evolution of the barrier and back-barrier basins of Belgium and the Netherlands as a function of late Weichselian morphology, relative sea-level rise and sediment supply. Netherlands Journal of Geosciences 79: 3-16.

Berger, G.W., Eisma, D. \& Van Bennekom, A.J., 1987. ${ }^{210} \mathrm{~Pb}$ derived sedimentation rate in the Vlieter, a recently filled-in channel in the Wadden Sea. Netherlands Journal of Sea Research 21: 287-294.

Biegel, E. J., 1993. Morphological changes due to sea-level rise in tidal basins in the Dutch Wadden Sea versus morphological response model MORRES. Report IMAU-93.14. Institute for marine and atmospheric research Utrecht. Faculty of Geographical Sciences (Utrecht): $124 \mathrm{pp}$.

Biegel, E. \& Hoekstra, P., 2009. Morphological response characteristics of the Zoutkamperlaag Inlet, Frisian Inlet, the Netherlands, to a sudden basin area reduction. In: Flemming, E. \& Bartholomä, A. (eds): Tidal Signatures in Modern and Ancient Sediments. Blackwell Publishing Ltd. (0xford, UK): 85-99.

Boon, J., Dardengo, L., \& Kernkamp, H., 2002. Alternative dumping sites in the Ems-Dollard estuary. Model study. Report Z3328. Deltares (Delft), 79 pp.

Bruun, $\boldsymbol{P}_{.}, 1962$. Sea-level rise as a cause of shore erosion. Journal of Waterways Harbors Division 88: 117-130.

Burchard, H., Flöser, G., Staneva, J.V., Badewien, T.H. \& Riethmüller, R., 2008. Impact of density gradients on net sediment transport into the Wadden Sea. Journal of Physical 0ceanography 38: 566-587.

Cahoon, D.R., French, J.R., Spencer, T., Reed, D. \& Möller, I., 2000. Vertical accretion versus elevation adjustment in UK saltmarshes: an evaluation of alternative methodologies. In: Pye, K. \& Allen, J.R.L. (eds): Coastal and Estuarine Environments. Special Publications, vol. 175. Geological Society (London): 223-238.

Cheung, K.F., Gerritsen, F. \& Cleveringa, J., 2007. Morphodynamics and sand bypassing at Ameland Inlet, the Netherlands. Journal of Coastal Research, 23(1): 106-118.

Cleveringa, J. \& Oost, A.P., 1999. The fractal geometry of tidal-channel systems in the Dutch Wadden Sea. Geologie en Mijnbouw 78: 21-30.

Cleveringa, J., Mulder, S. \& Oost, A.P., 2004. Kustverdediging van de koppen van de Waddeneilanden. De dynamiek van de kust nabij buitendelta's en passende maatregelen voor kustbeheer. Report RIZK/2004.017 (in Dutch). Rijkswaterstaat, National Institute for Coastal and Marine Management RIKZ (The Hague), $69 \mathrm{pp}$. 
Cleveringa, J., Israel, C.G. \& Dunsbergen, D.W., 2005. De Westkust van Ameland. Resultaten van 10 jaar morfologisch onderzoek in het kader van de Rijkswaterstaatprogramma's KUST2000 en KUST2005. Report RIKZ/2005.029 (in Dutch). Rijkswaterstaat, National Institute for Coastal and Marine Management RIKZ (The Hague), 74 pp.

Cleveringa, J., 2008. Ontwikkeling sedimentvolume Eems-Dollard en het Groninger wad: Overzicht van de beschikbare kennis en gegevens. Rapport A2269R1r3 (in Dutch). Alkyon, Marknesse, 47 pp.

Dastgheib, A., Roelvink, J.A. \& Wang, Z.B., 2008. Long-term process-based morphological modeling of the Marsdiep Tidal Basin. Marine Geology 256: 90-100.

Davis, R.A. \& Hayes, M.O., 1984. What is a wave-dominated coast? Marine Geology 60: 313-329.

Dean, R.G., 1988. Sediment interaction at modified coastal inlets: processes and policies. In: Aubrey, D. \& Weishar, L. (eds): Hydrodynamics and Sediment Dynamics of Tidal Inlets, Lecture Notes on Coastal and Estuarine Studies, 29, Springer (New York): 412-439.

De Boer, M., Kool, G., Lieshout, M.F. \& Ulm, D.L., 1991. Erosie en sedimentatie in de buitendelta van het Zeegat van Ameland en aangrenzende kuststroken 1926-1982. Report ANVX-91.H205 (in Dutch). Rijkswaterstaat, Directie NoordHolland (Haarlem), $30 \mathrm{pp}$.

De Glopper, R.J., 1967. Over de bodemgesteldheid van het Waddengebied (in Dutch). Van Zee tot Land, 43. Tjeenk Willink (Zwolle), $67 \mathrm{pp}$.

De Kok, J.M., 2005. Morfologische effecten van de Eijerlandse dam, een evaluatie. Report RIKZ/2005.003 (in Dutch). Rijkswaterstaat, National Institute for Coastal and Marine Management RIKZ (The Hague), 82 pp.

De Kruif, A.C., 2001. Bodemdieptegegevens van het Nederlandse Kustsysteem. Beschikbare digitale data en een overzicht van aanvullende analoge data. Report RIKZ/2001.041 (in Dutch). Rijkswaterstaat, National Institute for Coastal and Marine Management RIKZ (The Hague), 114 pp.

De Mulder, E.F.J., Geluk, M.C., Ritsema, I.L., Westerhoff, W.E. \& Wong, T.E., 2003. De Ondergrond van Nederland (in Dutch). Wolters-Noordhof bv (Groningen/Houten), $379 \mathrm{pp.}$

Deltacommissie, 1960. Rapport Deltacommissie. Deel. 1. Eindverslag en interimadviezen (in Dutch). ‘s-Gravenhage: Staatsdrukkerij- en Uitgeverijbedrijf (The Hague), $173 \mathrm{pp}$.

Eisma, D. \& Wolff, W. J., 1980. The development of the western most part of the Wadden Sea in historical time. In: Dijkema, K.S., Reineck, H.E. \& Wolff, W.J. (eds): Geomorphology of the Wadden Sea area. Balkema (Rotterdam): 95-103.

Elias, E.P.L., Stive, M.J.F., Bonekamp, J.G. \& Cleveringa, J., 2003. Tidal inlet dynamics in response to human intervention. Coastal Engineering Journal 45(4): 629-658.

Elias, E.P.L., Stive, M.J.F. \& Roelvink, J.A., 2005. Influence of stratification on flow and sediment transports in Texel inlet. Proceedings of Coastal Dynamics 2005. Barcelona.

Elias, E.P.L. \& Van der Spek, A.J.F., 2006. Long-term evolution of Texel Inlet and its ebb-tidal delta (the Netherlands). Marine Geology 225: 5-21.

Elias, E.P.L., 2006. Morphodynamics of Texel Inlet. Ph.D. thesis, Delft University of Technology, Faculty of Civil Engineering and Geosciences (Delft), 261 pp.

Eysink, W.D. \& Biegel, E.J., 1992. Impact of sea-level rise on the morphology of the Wadden Sea in the scope of its ecological function. ISOS*2 Project, phase 2. Report H1300, WL | Delft Hydraulics (Delft), 47 pp.
Flemming, B.W. \& Davis, R.A., 1994. Holocene evolution, morphodynamics and sedimentology of the Spiekeroog barrier island system (Southern North Sea). Senckenbergiana Maritima 24 (1/6): 117-155.

FitzGerald, D.M. \& Penland, S., 1987. Backbarrier dynamics of the East Friesian Island. Journal of Sedimentary Petrology 57: 746-754.

FitzGerald, D.M., 1988. Shoreline erosional-depositional processes associated with tidal inlets. In: Aubrey, D. \& Weishar, L. (eds): Hydrodynamics and Sediment Dynamics of Tidal Inlets, Lecture Notes on Coastal and Estuarine Studies. 29. Springer (New York): 186-225.

FitzGerald, D.M., 1996. Geomorphic variability and morphologic and sedimentologic controls on tidal inlets. Journal of Coastal Research 23: 47-71.

FitzGerald, D.M., Kraus, N.C. \& Hands, E.B., 2000. Natural Mechanisms of Sediment Bypassing at Tidal Inlets, Coastal and Hydraulics Engineering Technical Note, ERDC/CHL CHETN-IV-30. US Army Engineer Research and Development Center (Vicksburg, MS), 20 pp.

Glim, G.W., De Graaff, N., Kool, G., Lieshout, M.F. \& De Boer, M., 1988. Erosie en Sedimentatie in de Buitendelta van het Zeegat van Texel en Aangrenzende Kuststroken 1925-1981. Report ANWX-88.H201 (in Dutch). Rijkswaterstaat, Directie Noord-Holland (Haarlem), $36 \mathrm{pp}$.

Glim, G.W., Kool, G., Lieshout, M.F. \& De Boer, M., 1990. Erosie en Sedimentatie in de Buitendelta van het Eierlandse Gat en Aangrenzende Kuststroken 19261983. Report ANWX-88.H204 (in Dutch). Rijkswaterstaat, Directie NoordHolland (Haarlem), 35 pp.

Hallewas, D.P., 1984. The interaction between man and his physical environment in the county of Holland between circa 1000 and 1300 AD: a dynamic relationship. Geologie en Mijnbouw 62: 299-307.

Hibma, A., De Vriend, H.J. \& Stive, M.J.F., 2003. Numerical modeling of shoal pattern formation in well-mixed elongated estuaries. Estuarine, Coastal and Shelf Science 57: 981-991.

Hoeksema, H.J., Mulder, H.P.J., Rommel, M.C., De Ronde, J.G. \& De Vlas, J., 2004. Bodemdalingstudie Waddenzee 2004. Vragen en onzekerheden opnieuw beschouwd. Report RIKZ/2004.025 (in Dutch). Rijkswaterstaat, National Institute for Coastal and Marine Management RIKZ (Haren): 138 pp.

Hoogervoorst, R.D.N., 2005. Inventarisatie Bagger-, Stort- en Zandwingegevens binnen de -20 m NAP ten behoeve van een Zandbalans van het Nederlands Kustsysteem. Report RIKZ/KW/2005.103W (in Dutch). Rijkswaterstaat, National Institute for Coastal and Marine Management RIKZ (The Hague), 59 pp.

Israel, C.G. \& Dunsbergen, D.W., 1999. Cyclic morphological development of the Ameland Inlet, the Netherlands. Proceedings of Symposium on River, Coastal and Estuarine Morphodynamics (Genova, Italy), Volume 2: 705-714.

Joustra, D.S., 1973. Geulbeweging in de buitendelta's van de Waddenzee (in Dutch), Report WWK 71-14 (in Dutch). Rijkswaterstaat, Directie Waterhuishouding en Waterbeweging (The Hague), $27 \mathrm{pp}$.

Katsman, C.A., Sterl, A., Beersma, J.J., Van den Brink, H.W., Hazeleger, W. \& 15 co-authors, 2011. Exploring high-end scenarios for local sea-level rise to develop flood protection strategies for a low-lying delta - the Netherlands as an example. Climatic Change 109(3): 617-645.

Kennish, M.J., 2001. Coastal salt marsh systems in the US: a review of anthropogenic impacts. Journal of Coastal Research 17(3): 731-748.

Lesser, G.R., Roelvink, J.A., Van Kester, J.A.T.M. \& Stelling, G.S., 2004. Development and validation of a three-dimensional model. Coastal Engineering 51: 883-915. 
Louters, T. \& Gerritsen, F., 1994. The Riddle of the Sands. A Tidal System's Answer to a Rising Sea Level. Report RIKZ-94.040. Rijkswaterstaat, National Institute for Coastal and Marine Management RIKZ (The Hague), 69 pp.

Madsen, A.T., Murray, A.S., Andersen, T.J. \& Pejrup, M., 2007. Temporal changes of accretion rates on an estuarine salt marsh during the late Holocene Reflection of local sea level changes? The Wadden Sea, Denmark. Marine Geology 242(4): 221-233.

Marciano, R., Wang, Z.B., Hibma, A., De Vriend, H.J. \& Defina, A., 2005. Modeling of channel patterns in short tidal basins. Journal of Geophysical Research, Earth Surface 110, 13 pp.

Meehl, G., Stocker, T.F., Collins, W.D., Friedlingstein, P., Gaye, A.T., Gregory, J.M., Kitoh, A., Knutti, R., Murphy, J.M., Noda, A., Raper, S.C.B., Watterson, I.G., Weaver, J. \& Zhao, Z.-C., 2007. Global climate projections. In: Solomon, S., Qin, D., Manning, M., Chen, Z., Marquis, M., Averyt, K.B., Tignor, M. \& Mille, H.L. (eds): Climate Change 2007: The Physical Science Basis. Contribution of Working Group 1 to the Fourth Assessment Report of the Intergovernmental Panel on Climate Change. Cambridge. University Press (Cambridge, UK and New York, USA), 996 pp.

Morris, J.T., Sundareshwar, P.V., Nietch, C.T., Kjerfve, B. \& Cahoon, D.R., 2002. Responses of coastal wetlands to rising sea level. Ecology 83(10): 2869-2877.

Nichols, M.M., 1989. Sediment accumulation rates and relative sea-level rise in lagoons. Marine Geology 88: 201-219.

Nyandwi, N., 1998. Sediment distribution patterns in the back-barrier areas of the Wadden Sea, Spiekeroog Island, Germany. In: Alexander, C.R., Davis, R.A. \& Henry, V.J. (eds): Tidalites: Processes and Products, SEPM Special Publication 61: 15-22.

Oost, A.P. \& De Boer, P.L., 1994. Sedimentology and development of barrier islands, ebb-tidal deltas, inlets and backbarrier areas of the Dutch Wadden Sea. Senckenbergiana Maritima 24: 65-115.

Oost, A.P., 1995. Dynamics and Sedimentary Development of the Dutch Wadden Sea with Emphasis on the Frisian Inlet. A Study of Barrier Islands, Ebb-Tidal Deltas, Inlets and Drainage Basins. Geologica Ultraiectina, Mededelingen van de Faculteit Aardwetenschappen, Utrecht University (Utrecht): $454 \mathrm{pp}$.

Perluka, R., Wiegmann, E.B., Jordans, R.W.L. \& Swart, L.M.T., 2006. Opnametechnieken Waddenzee. Report AGI-2006-GPMP-004 (in Dutch). Rijkswaterstaat Adviesdienst Geo Informatie en ICT, 47 pp.

Pilkey, 0.H., Young, R.S., Riggs, S.R., Smith, A.W.S., Wu, H. \& Pilkey, W.D., 1993. The concept of shoreface profile of equilibrium: A critical review. Journal of Coastal Research 9(1): 255-278.

Pons, L.J. \& Van Oosten, M.F., 1974. De bodem van Noord-Holland (in Dutch). Stiboka (Wageningen), $193 \mathrm{pp}$.

Postma, H., 1954. Hydrography of the Dutch Wadden Sea. Archives Néerlandaises de Zoologie 10: 405-511.

Postma, H., 1961. Transport and accumulation of suspended matter in the Dutch Wadden Sea. Netherlands Journal of Sea Research 1: 148-190.

Pugh, D. T., 2004. Changing Sea Levels: Effects of Tides, Weather, and Climate. Cambridge University Press (Cambridge, UK), 267 pp.

Rakhorst, H.D., 1986. Erosie en Sedimentatie in de Buitendelta van het Zeegat van het Vlie en Aangrenzende Kuststroken 1926-1984. Report ANWX-86H210 (in Dutch). Rijkswaterstaat, Directie Noord-Holland (Haarlem), 25 pp.

Rakhorst, H.D., 1999. Evaluatie Zeewaartse Kustverdediging. Texel-Dam Eijerland. Report (in Dutch). Rijkswaterstaat, Directie Noord-Holland (Haarlem), 33 pp.
Renger, E. \& Partenscky, H.W., 1974, Stability criteria for tidal basins, Proceedings $14^{\text {th }}$ Coastal Engineering Conference, ASCE, Copenhagen, Denmark 2: 1605-1618.

Rietveld, C.F.W., 1962. The natural development of the Wadden Sea after the enclosure of the Zuider Sea. Proceedings $8^{\text {th }}$ International Conference on Coastal Engineering, ASCE, Mexico City: 765-781.

Roelse, P., 2002. Water en Zand in Balans. Evaluatie Zandsuppleties na 1990; Een Morfologische Beschouwing. Report RIKZ/2002.003 (in Dutch). Rijkswaterstaat, National Institute for Coastal and Marine Management RIKZ (Middelburg), $108 \mathrm{pp}$.

Rijzewijk, L.C., 1986. Overzichtskaarten Zeegaten van de Waddenzee, 1976-1985. Report 86.H208 (in Dutch). Rijkswaterstaat, Directie Noord-Holland (Haarlem).

Roskam, A.P., 1988. Golfklimaten voor de Nederlandse Kust. Report GWA0-88.046 (in Dutch). Rijkwaterstaat, Tidal Waters Department (The Hague), 69 pp.

Schoorl, H., 1973. Zeshonder Jaar Water en Land: bijdrage tot de historische geoen hydrografie van de Kop van Noord-Holland in de periode 1150-1750 (in Dutch). Wolters-Noordhoff (Groningen), $534 \mathrm{pp}$.

Schoorl, H., 1999. De convexe kustboog Texel-Vlieland-Terschelling: bijdragen tot de kennis van het westelijk Waddengebied en de eilanden Texel, Vlieland en Terschelling: 1. Het westelijk Waddengebied en het eiland Texel tot circa 1550 (in Dutch). Pirola (Schoorl), 187 pp.

Schoorl, H., 2000a. De convexe kustboog Texel-Vlieland-Terschelling: bijdragen tot de kennis van het westelijk Waddengebied en de eilanden Texel, Vlieland en Terschelling: 2. Het Westelijk Waddengebied en het Eiland van Texel vanaf circa 1550 (in Dutch). Pirola (Schoorl), 366 pp.

Schoorl, H., 2000b. De convexe kustboog Texel-Vlieland-Terschelling: bijdragen tot de kennis van het westelijk Waddengebied en de eilanden Texel, Vlieland en Terschelling: 3. Vlieland (in Dutch). Pirola (Schoorl), 188 pp.

Schoorl, H., 2000c. De convexe kustboog Texel-Vlieland-Terschelling: bijdragen tot de kennis van het westelijk Waddengebied en de eilanden Texel, Vlieland en Terschelling: 4. Terschelling (in Dutch). Pirola (Schoorl), 252 pp.

Sha, L.P., 1989. Variation in ebb-tidal delta morphologies along the west and East Frisian Islands, the Netherlands and Germany. Marine Geology 89: 11-28.

Sha, L.P., 1990. Sedimentological Studies of the Ebb-Tidal Deltas along the West Frisian Islands, the Netherlands. Geologia Ultaiectina, Mededelingen van de Faculteit Aardwetenschappen 64, University Utrecht (Utrecht), 159 pp.

Shchepetkin, A.F. \& McWilliams, J.C., 2005. The Regional 0cean Modeling System: A split-explicit, free-surface, topography following coordinates ocean model, Ocean Modeling 9: 347-404.

Stive, M.J.F. \& Eysink, W.D., 1989. Voorspelling Ontwikkeling Kustlijn 1990-2090. Fase3. Deelrapport 3.1: Dynamisch Model van het Nederlandse Kustsysteem. Report H825 (in Dutch). Waterloopkundig Laboratorium (Delft), 66 pp.

Stive, M.J.F., Wang, Z.B., Ruol, P., \& Buijsman, M.C., 1998. Morphodynamics of a tidal lagoon and adjacent coast. Proceedings 8th International Biennial Conference on Physics of Estuaries and Coastal Seas (The Hague): 397-407.

Stive, M.J.F. \& Wang, Z.B., 2003. Morphodynamic modeling of tidal basins and coastal inlets. In: Lakhan, C. (ed.): Advances in Coastal Modeling. Elsevier Oceanography Series 67: 367-392.

Thijsse, J.T., 1972. Een Halve Eeuw Zuiderzeewerken 1920-1970 (in Dutch). Tjeenk Willink (Groningen), 469 pp.

Van der Molen, J. \& Van Dijck, B., 2000. The evolution of the Dutch and Belgian coast and the role of sand supply from the North Sea. Global and Planetary Change 27: 223-244. 
Van der Spek, A.J.F. \& Noorbergen, H.H.S., 1992. Morfodynamica van Intergetijdegebieden. Report 92-03 (in Dutch). Beleidscommissie Remote Sensing BCRS, $34 \mathrm{pp}$.

Van der Spek, A.J.F. \& Beets, D.J., 1992. Mid-Holocene evolution of a tidal basin in the western Netherlands; a model for future changes in the northern Netherlands under conditions of accelerated sea-level rise? Sedimentary Geology 80: 185-197.

Van der Spek, A.J.F., 1994. Large-Scale Evolution of Holocene Tidal Basins in the Netherlands. Ph.D. thesis, Utrecht University (Utrecht), 191 pp.

Van der Spek, A.J.F., 1995. Reconstruction of tidal inlet and channel dimensions in the Frisian Middelzee, a former tidal basin in the Dutch Wadden Sea. In: Flemming, B.W., Bartholomä, A. (eds): Tidal Signatures in Modern and Ancient Sediments, Special Publications International Association of Sedimentologists 24: 239-258.

Van der Wegen, M., Wang, Z.B., Savenije, H.H.G. \& Roelvink, J.A., 2008. Longterm morphodynamic evolution and energy dissipation in a coastal plain, tidal embayment. Journal of Geophysical Research, Earth Surface 113, 22 pp.

Van der Wegen, M., \& Roelvink, J.A., 2008. Long-term morphodynamic evolution of a tidal embayment using a two-dimensional, process-based model, Journal of Geophysical Research, 0ceans 113, 23 pp.

Van Goor, M.A., Zitman, T.J., Wang, Z.B. \& Stive, M.J.F., 2003. Impact of sealevel rise on the morphological equilibrium state of tidal inlets. Marine Geology 202: 211-227.

Van Koningsveld, M. \& Mulder, J.P.M., 2004. Sustainable Coastal Policy Developments in the Netherlands. A Systematic Approach Revealed. Journal of Coastal Research 20(2): 375-385.

Van Ledden, M., 2003. Sand-mud segregation in estuaries and tidal basins. Ph.D. thesis, Delft University of Technology, Faculty of Civil Engineering and Geosciences (Delft), $221 \mathrm{pp}$.

Van Straaten, L.M.J.U., 1954. Composition and structure of recent marine sediments in the Netherlands. Leidse Geologische Mededelingen, 19: 1-110.

Van Straaten, L.M.J.U. \& Kuenen, P.H., 1957. Accumulation of fine-grained sediments in the Dutch Wadden Sea. Geologie en Mijnbouw, 19: 329-354.

Van Straaten, L.M.J.U., 1975. De sedimenthuishouding van de Waddenzee. In: Swennen, C., De Wilde, P.A.W.J. \& Haeck, J. (eds): Symposium Waddenonderzoek, April 7, 1973 (in Dutch, with English summary). Mededeling Werkgroep Waddenzee 1 (Amsterdam): 5-20.

Van Veen, J., 1936. Onderzoekingen in den Hoofden in verband met de gesteldheid des Nederlandse kust. Ph.D. thesis, Leiden University (Leiden), 252 pp.

Van Wijnen, H.J. \& Bakker, J.P., 2001. Long-term surface elevation change in salt marshes: a prediction of marsh response to future sea-level rise. Estuarine Coastal Shelf Science 52: 381-390.

Vos, P.C., Weerts, H.J.T., Bazelman, J., Hoogendoorn, B, \& Van der Meulen, M.J.M., 2011. Atlas van Nederland in het Holoceen. Bert bakker (Amsterdam), $94 \mathrm{pp}$.

Walburg, L., 2001. De Zandbalans van het Zeegat van Texel bepaald met Verschillende Buitendelta-Definities. Report RIKZ/OS 2001 (in Dutch). Rijkswaterstaat, National Institute for Coastal and Marine Management RIKZ (The Hague), $51 \mathrm{pp}$.
Wang, Z.B., De Vriend, H.J., Stive, M.J.F. \& Townend, I.H., 2007. On the parameter setting of semi-empirical long-term morphological models for estuaries and tidal lagoons, In: Dohmen-Jansen, C.M. \& Hulscher S.J.M.H., (eds): River, Coastal and Estuarine Morphodynamics, RCEM2007, Taylor \& Francis (London): 103-111.

Wang, Z.B., Vroom, J., Van Prooijen, B.C., Labeur, R.J., Stive, M.J.F. \& Hansen, M.H.P., 2011. Development of tidal watersheds in the Wadden Sea. RCEM 2011: Proceedings of the $7^{\text {th }}$ IAHR Symposium of River, Coastal and Estuarine Morphodynamics (Beijing, China): 493-504.

Westenberg, J., 1974. Kennemer dijkgeschiedenis (in Dutch). Verhandelingen der Koninklijke Nederlandse Akademie Van Wetenschappen, Afd. Natuurkunde, volume 27. Noord-Hollandse Uitg. Mij., 159pp.

Wiegmann, E.B., Perluka, R., Oude Elberink, S. \& Vogelzang, J., 2005. Vaklodingen: De Inwintechnieken en hun Combinaties. Report AGI-2005GSMH-012 (in Dutch). Rijkswaterstaat, Adviesdienst GeoInformatie: 47 pp.

Wijnberg, K.M., 1995. Morphologic Behavior of a Barred Coast over a Period of Decades. Ph.D. thesis, University Utrecht, Faculty of Geographical Sciences (Utrecht), $245 \mathrm{p}$.

Zagwijn, W.H., 1986. Nederland in het Holoceen. Geological Survey of the Netherlands (Haarlem), 46 pp. 